\title{
Trust in Collective Entrepreneurship in the Context of the Development of Rural Areas in Poland
}

\author{
Leszek Sieczko $^{1, * \mathbb{D}}$, Anna Justyna Parzonko ${ }^{2} \mathbb{D}$ and Anna Sieczko ${ }^{2}$ \\ 1 Department of Biometry, Institute of Agriculture, Warsaw University of Life Sciences-SGGW, \\ 02-787 Warsaw, Poland \\ 2 Department of Tourism, Social Communication and Consulting, Institute of Economics and Finance, \\ Warsaw University of Life Sciences-SGGW, 02-787 Warsaw, Poland; anna_parzonko@sggw.edu.pl (A.J.P.); \\ anna_sieczko@sggw.edu.pl (A.S.) \\ * Correspondence: leszek_sieczko@sggw.edu.pl
}

Citation: Sieczko, L.; Parzonko, A.J.; Sieczko, A. Trust in Collective Entrepreneurship in the Context of the Development of Rural Areas in Poland. Agriculture 2021, 11, 1151. https://doi.org/10.3390/ agriculture11111151

Academic Editors: Adoración Mozas Moral and Domingo Fernandez Ucles

Received: 19 October 2021

Accepted: 11 November 2021

Published: 16 November 2021

Publisher's Note: MDPI stays neutral with regard to jurisdictional claims in published maps and institutional affiliations.

Copyright: (c) 2021 by the authors. Licensee MDPI, Basel, Switzerland. This article is an open access article distributed under the terms and conditions of the Creative Commons Attribution (CC BY) license (https:/ / creativecommons.org/licenses/by/ $4.0 /)$.

\begin{abstract}
The aim of this research was to examine whether trust influences the functioning of various forms of collective entrepreneurship in rural areas. The study focused on organizations which are most common in rural Poland: agricultural producer organizations, rural women's circles, and local action groups. Hence, the survey sample included people engaged in these types of collective entrepreneurship. Data collection was based on a standardized questionnaire distributed online utilizing the computer-assisted web interviewing method. The statistical analysis of the empirical material obtained from 132 respondents involved Pearson and Spearman correlation and principal component analysis. The conducted research shows (1) the superior role of personal trust over institutional trust in the emergence and functioning of the studied forms of collective entrepreneurship in rural areas, (2) the greater importance of social than economic factors determining the functioning of rural collective entrepreneurship, (3) the positive impact of generalized trust on trust placed in the forms of entrepreneurship covered by the analysis, (4) the increase in trust over time of cooperation, and (5) the impact of trust on the functioning of collective entrepreneurship, in both the economic and the social dimensions, with a slight advantage of the latter. By focusing on trust, this article contributes to the literature on the role of trust in developing collective entrepreneurship in rural areas. The authors point out that this article only opens the space for a discussion on trust in the concept of the economics of trust.
\end{abstract}

Keywords: agricultural producer organizations; rural women's circles; local action groups

\section{Introduction}

In Poland, rural areas have great social, environmental, and economic importance. This is mainly due to the fact that they cover the vast majority of the country's area and are inhabited by a high percentage of the population. The political transformation in Poland in 1989 revealed that, despite the fact that most of the farms were privately owned, farmers were not prepared for the changes that followed. One of the negative effects of the transformation was unemployment, practically unknown in Poland after World War II. It became obvious that unprofitable agricultural production had to be replaced by new off-farm jobs or additional on-farm activities. The structure of Polish agriculture is highly fragmented. Private sector farms dominate, including family farms, which account for slightly more than $99 \%$ of the total number of farms. As for the farm size, in 2019, more than half of the households were small farms with agricultural land not exceeding 5 ha (53.5\%). The largest farms with an area of 50 ha of agricultural land accounted for only $2.4 \%$. The average agricultural land per farm has remained at the level of approximately 10 ha for several years [1]. The agricultural policy implemented after the political transformation and after Poland's accession to the European Union has not led to an improvement in the structure of Polish agriculture. The productivity of the factors of production, especially 
labor, is unsatisfactory. It is visible mainly in the weak flow of land from farms that are not very productive or use land poorly to farms that are more effective in this respect. The agrarian structure of Polish agriculture remains flawed, especially when compared to other European Union countries. Currently, over $70 \%$ of economically active people living in rural areas do not derive any income from agriculture [2]. Micro-enterprises based on self-employment dominate in the employment structure. Thus, there is an increase in nonagricultural jobs in rural areas, but it is too low to meet the needs of the existing rural surplus of labor. For this reason, Polish rural areas and agriculture require continuous support for modernization and restructuring, as well as strengthening their competitive position in global markets.

The socioeconomic development of rural areas is a derivative of many factors, the importance of which cannot be overestimated. Some of them are exogenous, partly or totally independent of the activities of the local community, while others are endogenous. Research on the use of available resources (endogenous and exogenous) located in rural areas is necessary in order to stimulate positive attitudes toward entrepreneurial initiatives, including collective endeavors. In the literature, attitudes of this type are referred to as entrepreneurial attitudes [3-5].

The concept of entrepreneurship is often discussed in the literature. Entrepreneurship is a multidimensional phenomenon. All attempts to define the concept of "entrepreneurship" prove its interdisciplinarity. It has been a point of interest for researchers representing scientific disciples, such as psychology, sociology, economics, and management. Most often, entrepreneurship is associated with economic issues and a certain attitude involving looking for opportunities and achieving specific goals. In the literature on management and economics, entrepreneurship is most often treated as a process. In this case, the essence of entrepreneurship lies in initiating projects, as well as new forms of activity that would satisfy the needs and generate profits, and it would enable the reproduction and development of entrepreneurship. Entrepreneurship understood as a process involves activities undertaken in a specific space and time, with the use of specific resources by entities characterized by the features and skills desired in this process.

Entrepreneurship in the economic dimension involves the following [6,7]:

- creating new companies;

- increasing efficiency;

- creating new products, services, and techniques;

- revitalizing competition in the market.

Another understanding of entrepreneurship as a process assumes that it is the course of action involving setting up and running a business, including the following components: identifying opportunities and possibilities for operating on the market, developing a business plan and gathering the necessary resources, setting up an enterprise, and leading it through the subsequent phases of its development. Therefore, we can risk a statement that entrepreneurship is an organized activity, focused on the ability to generate and use innovative ideas in order to obtain measurable benefits, carried out under risk conditions [5,8-10].

When considering entrepreneurship in rural areas, one should not only focus on setting up and running a business [11]. Such an approach would considerably narrow the concept itself, as it also includes other activities contributing to the multidimensional development of rural areas, such as the activities of rural women's circles or local action groups. Then, entrepreneurship is associated with the attitude of a person toward the outside world and is expressed in a creative and active pursuit of new activities or expansion of the existing ones. Entrepreneurship can also be understood as a specific type of human activity, defined by behavior, the ability to use ideas, and opportunities that come unnoticed or are underestimated by others. Entrepreneurship, understood as a specific type of human endeavor, may take the form of an individual or collective activity. Collective entrepreneurship can be understood as organized, conscious, and voluntary cooperation of people aimed at achieving a common goal [12]. Its essence is the expression of the 
interests of the group and the representation of these interests in the external environment. It requires close working relationships between people, utilization of their talents and creative abilities, and mutual trust.

Trust can appear at different levels of social life. It may arise as a result of direct contacts and strong family and friendship ties in the traditional culture of the community, as well as in communities where secondary groups dominate, as a result of participation in the workplace environment, associations, and civic groups [13]. In the former case, the trust phenomenon derives from mutual relations: the more reciprocal the relations between individual members of the community or positive experiences in neighborly cooperation, the greater the credit of trust. In the latter case, trust is generalized and is based on a generally positive attitude toward others and public institutions. Trust in a situation of cooperation means that there is a widespread belief that others will participate in cooperation to a similar extent, that cooperation will be based on the principles of fair play, and that it is "profitable", i.e., brings benefits for all partners $[14,15]$.

Collaborative networks are mutual relations that take place between individual members of a community, informal groups, and formal organizations. Through them, the community establishes strategic contacts, selects leaders, defines and agrees with local interests, identifies problems, and mobilizes material resources and residents to solve them [16]. People and organizations within such networks often gain two benefits: influence and power. They have greater opportunities to negotiate various types of transactions, because they have easier access to information, as well as greater control over its circulation and, thus better chances to use the emerging opportunities. Local leaders play a huge role in their use [14]. One of the programs facilitating the network cooperation in rural areas is the LEADER program, which contributes to the activation of rural communities by involving social and economic partners in the planning and implementation of local initiatives. It is a program implemented by local action groups (LAGs), which by linking representatives of three sectors, public, economic, and social, contribute to strengthening social capital and economic development of rural areas. Another manifestation of the cooperation network in rural areas, which has tradition dating back to the 19th century, is represented by rural women's circles. They represent the interests and work to improve the social and professional situation of rural women and their families, as well as support the comprehensive development of rural areas. Next, there are agricultural producer organizations, created to enable farmers to become partners for large buyers of agricultural products, as well as means of production. As an organization, farmers are able to meet the increasing requirements imposed by the market regarding the quality of agricultural and food products, but also share expenses on the purchase of equipment or organization of transport, negotiate contracts, trade together in the marketplace, or undertake marketing activities.

The abovementioned forms of collective entrepreneurship are part of the new direction of rural development by creating conditions for effective, efficient, and partnership-based implementation of territorially oriented development activities. The literature suggests that, in this area, it is important to support the so-called collective trust, so that the participants can share their experiences, be open to creative ideas, and find new directions for their enterprises through mutual help and support [17-20].

A manifestation of favorable changes in the perception of the impact of various factors on the economy, including the "soft" ones, is the development of a new trend in economic sciences-the economics of trust. Traditional (neoclassical) economics, despite being a social science, took into account only one type of human behavior, based on rational principle and driven by the maximization of utility [21,22]. The exclusion of social aspects from the analyses, which has been described in the literature as "desocialization" [23], was one of the levels of criticism of mainstream economics and the reason for a significant limitation of its ability to explain many phenomena. Evidence provided by behavioral economics [24], experimental economics [25], or game theory [26] shows that individuals not only assume the existence of noneconomic values, but also make choices guided by these values. One of such values is trust, which plays a crucial role in both social and economic life [27]. 
In business, trust is recognized as an important component of success [28,29]. The economics of trust is detectable at various levels of social and economic life, from saving money that would have to be spent on security, to improving the functioning of the political system. However, primarily, trust fosters business relationships. Employees who trust each other are more collaborative and more willing to share ideas and information, which facilitates innovation and ultimately increases productivity [30,31]. Lack of trust may stimulate hesitant attitudes toward teamwork or even antisocial attitudes when team members hold back good ideas or vital observations and do not share their experiences with each other [32]; they also have lower tolerance for organizational change [33]. Consequently, absence of trust leads to lower wages, profits, and employment, while its presence facilitates trade and encourages activities that add economic value [34]. In this sense, trust is like an interdependent network that connects all actors in an economy and determines how they interact to drive the economic growth $[35,36]$.

Research in the field of the economics of trust is based on the thesis that trust is related to equality understood in two dimensions: economic equality and equal opportunities [37]. In countries with a high level of generalized trust, the level of economic equality and equal opportunities is high [38], in contrast to countries with a low level of generalized trust. It is also visible in the approach to entrepreneurship. Specifically, societies characterized by economic equality and equal opportunities, i.e., open, knowledge-based societies with a well-developed welfare state, have the best conditions for intrapreneurship and ultimately economic growth [39]. It is worth emphasizing that trust, both institutional and individual, tends to decline when socioeconomic conditions deteriorate $[40,41]$.

Nature of the relationship between generalized trust and economic dynamics is still minimally explored and understood, and the research carried out so far is mainly positioned in a macroeconomic perspective [42].

The aim of the presented research was to find an answer to the question whether and to what extent trust influences the functioning of various forms of collective entrepreneurship in rural areas. We focused on those forms of collective entrepreneurship that are common in Poland-agricultural producer organizations, rural women's circles, and local action groups.

The issue of trust and its role in the creation and management of an enterprise have been widely discussed in the literature. However, the researchers mostly focused on its role in three areas of economic behavior: consumption of goods and services, relations between enterprises, and the superior-subordinate relationship. Unfortunately, the rural context has largely been neglected. As emphasized by Gillath, Ai, Branicky, Keshmiri, Davison, and Spaulding [43], the lack of trust (whatever the cause) can result in limited cooperation, efficiency, and productivity. Few researchers have focused on trust in collective entrepreneurship, which makes this study fit into the existing research gap.

Given the lack or a very limited scale of research focused on trust in collective entrepreneurship in rural areas, and having taken into account its role in business management and in economic and social development, the following research hypotheses were formulated:

Hypothesis 1 (H1). People engaged in the studied forms of collective entrepreneurship in rural areas have greater personal than institutional trust.

Hypothesis 2 (H2). Social factors determine the functioning of the studied forms of collective entrepreneurship to a greater extent than economic factors.

Hypothesis 3 (H3). According to the concept of the economics of trust, the higher the level of generalized trust is, the higher the trust in various forms of cooperation will be. 


\section{Research Methods}

The empirical research made it possible to verify the formulated research hypotheses. The survey based on a standardized questionnaire was carried out online using the computer-assisted web interviewing method (CAWI), which, in the situation of the COVID-19 pandemic and restrictions on direct social contacts, was one of very few possibilities to collect empirical data. The CAWI method enables quantitative measurement through questionnaires provided via the Internet. The method makes it possible to reach large samples, while ensuring the respondents' anonymity [44]. The proprietary questionnaire was prepared on the ProfiTest platform between June and July 2021. The link to the survey was made available via social media on profiles related to agriculture and rural areas, as well as posted to organizations whose e-mail addresses were obtained from registers kept by the Agency for Restructuring and Modernization of Agriculture: Register of Pre-Recognized Producer Organizations, Recognized Producer Organizations, and their Associations, as well as Transnational Producer Organizations and their Associations on the Fruit and Vegetables Market, Register of Agricultural Producer Groups, National Register of Rural Women's Circles, and Local Action Groups Register 2014-2020 held by the National Network of Rural Areas. We also planned to include members of the voluntary fire brigades, which have a large representation in the rural areas. The link to the questionnaire was posted on thematic Internet forums and sent by e-mail to all the Voivodship Branches of the Volunteer Fire Brigade Associations of the Republic of Poland. Unfortunately, only a few incomplete questionnaires were received in response; therefore, they could not be included in further analysis.

The survey questionnaire consisted mainly of closed rating questions with an 11-point Likert scale. In total, correctly completed questionnaires were obtained from 132 respondents representing the types of organizations selected for the study.

As can be seen from the data presented in Table 1, both the size of the studied population and its structure indicate that the sample cannot be treated as representative of a larger population. However, the overall number of correctly completed questionnaires justifies further analysis of the results.

Table 1. Characteristics of the sample.

\begin{tabular}{|c|c|c|c|c|}
\hline & & \multicolumn{3}{|c|}{ Form of Collective Entrepreneurship } \\
\hline & & $\begin{array}{c}\text { Agricultural Producer } \\
\text { Organization } \\
\text { (G1) }\end{array}$ & $\begin{array}{l}\text { Local Action Group } \\
\text { (G3) }\end{array}$ & $\begin{array}{l}\text { Rural Women's Circle } \\
\text { (G4) }\end{array}$ \\
\hline \multirow{2}{*}{ Gender } & Women & 6 & 42 & 59 \\
\hline & Men & 11 & 14 & - \\
\hline \multirow{3}{*}{ Education } & $\begin{array}{c}\text { Primary/lower } \\
\text { secondary/vocational }\end{array}$ & 1 & & 4 \\
\hline & Secondary/post-secondary & 8 & & 24 \\
\hline & Higher & 8 & 56 & 31 \\
\hline \multicolumn{2}{|c|}{$\begin{array}{c}\text { Average length of participation in the organization } \\
\text { (years) }\end{array}$} & 8.9 & 10.7 & 8.6 \\
\hline
\end{tabular}

The questionnaire examining various aspects of trust related to the studied forms of entrepreneurship was designed in such a way that the respondents, when answering each question, had the same 11-degree span. In questions Q8, Q9, Q10, and Q13 (for code descriptions, see Table 2), the scale was defined from -5 through 0 to +5 , so that the respondent could give negative and positive ratings. Neutral opinions could be indicated by choosing 0 or values close to it. Question Q11, which examined the importance of trust impact on various aspects of collective activities, involved a scale from 0 (not important) to 10 (very important). The initial dataset collected in this way was cleared of incomplete 
questionnaires. Finally, 132 data records were left for statistical analysis. Initially, the results were divided into three groups according to the type of organization represented by the respondent: agricultural producer organizations (G1), rural women's circles (G3), and local action groups (G4), for which basic statistics were calculated, including mean scores (Table 2).

Pearson and Spearman correlation analyses were conducted between the age of the respondents, the length of participation in an organization, and all answers from questions Q8 to Q13. A correlation matrix with dimensions of $54 \times 54$ was obtained (Appendix A, Tables A1-A4).

In the survey, we asked the respondents to assess their level of generalized trust. Depending on their answers, they fell into one of the three categories: (1) people who are generally trustful, (2) people who are cautious and distrustful in relations with others, and (3) people who cannot identify their attitude in this respect. As the declared trust was a very important factor in our research, further analyses were performed on the basis of a further division of respondents within the three existing groups (G1, G3, and G4) into three more groups depending on the declared trust (T1- trustful, T2-distrustful, and T3-unable to identify their attitude). Therefore, in further analyses, a division into nine groups was used, which were combinations of forms of collective entrepreneurship and the declared level of trust (G1T1, G1T2, G1T3, ... , G4T3).

For question Q8, in which the respondents assessed the degree of trust in a given organization at three stages of their engagement, an analysis of variance was performed, where the factor at nine levels was the division of respondents according to the form of entrepreneurship and the declared level of trust. A significance level of 0.05 was assumed.

For questions Q9 to Q13, due to a fairly large and detailed set of possible answers, principal component analysis (PCA) was performed. The main purpose of PCA was to facilitate the presentation of the relationship between the studied groups and the obtained results. In addition, a varimax rotation was used, which changes the position of the tested objects so that the individual components contain objects that are strongly correlated with each other and have little correlation with other components. The synthesis and the basis for the discussion were the biplots that contained plotted variants of responses correlated with the components in the two-dimensional space of the first two components (PC1 and PC2). The position of the tested nine groups in relation to the answers and components was also added to biplots. All analyses and graphical presentation of data were executed using IBM SPSS Statistics ver. 26.

Table 2. Mean values of ratings by three types of organizations (G1, G3, and G4).

\begin{tabular}{|c|c|c|c|}
\hline \multirow{2}{*}{ Question/Answer Code } & \multicolumn{3}{|c|}{ Organization Type Code } \\
\hline & G1 & G3 & G4 \\
\hline \multicolumn{4}{|c|}{$\begin{array}{l}\text { Q8-Question } 8 \text { (scale }-5 \text { to } 5 \text { ) } \\
\text { Please assess the degree of trust in the organization of which you are a member at three stages. }\end{array}$} \\
\hline Q8.1-before deciding to join & 2.824 & 3.109 & 3.175 \\
\hline Q8.2-at the beginning of cooperation & 3.471 & 3.655 & 3.684 \\
\hline Q8.3-currently & 3.471 & 3.618 & 3.614 \\
\hline \multicolumn{4}{|c|}{$\begin{array}{l}\text { Q9-Question } 9 \text { (scale }-5 \text { to } 5) \\
\text { Do you trust or not trust the following? }\end{array}$} \\
\hline Q9.1—immediate family_parents, children, spouse & 4.824 & 4.691 & 4.702 \\
\hline Q9.2-your friends & 3.059 & 3.455 & 3.456 \\
\hline Q9.3-extended family & 2.882 & 3.182 & 3.175 \\
\hline Q9.4-people with whom you work on a daily basis & 2.647 & 2.636 & 2.649 \\
\hline Q9.5-neighbors & 2.353 & 2.309 & 2.333 \\
\hline Q9.6-the local parish priest & 0.706 & 1.236 & 1.281 \\
\hline Q9.7-people who work voluntarily in your place of residence & 1.471 & 2.455 & 2.474 \\
\hline Q9.8-local entrepreneurs & 1.294 & 2.127 & 2.140 \\
\hline Q9.9-local teachers & 2.176 & 2.127 & 2.140 \\
\hline Q9.10-people with whom you cooperate in the organization & 3.176 & 3.345 & 3.368 \\
\hline
\end{tabular}


Table 2. Cont

\begin{tabular}{|c|c|c|c|}
\hline \multirow{2}{*}{ Question/Answer Code } & \multicolumn{3}{|c|}{ Organization Type Code } \\
\hline & G1 & G3 & G4 \\
\hline \multirow{2}{*}{\multicolumn{4}{|c|}{$\begin{array}{l}\text { Q10-Question } 10 \text { (scale }-5 \text { to } 5 \text { ) } \\
\text { Do you trust or not trust the following institutions? }\end{array}$}} \\
\hline & & & \\
\hline Q10.1—agricultural advisory centers & 2.412 & 2.782 & 2.860 \\
\hline Q10.2-private consulting/advisory firms & 0.588 & 1.345 & 1.368 \\
\hline Q10.3-local government & 1.118 & 1.236 & 1.298 \\
\hline Q10.4-agricultural chambers & 1.353 & 1.927 & 1.965 \\
\hline Q10.5-Polish Agency for Enterprise Development (PARP) & 0.765 & 1.545 & 1.596 \\
\hline $\begin{array}{l}\text { Q10.6-non-governmental organizations supporting entrepreneurship, e.g., business } \\
\text { incubators and technology parks }\end{array}$ & 0.882 & 1.909 & 1.930 \\
\hline Q10.7-commercial banks & 0.529 & 0.509 & 0.544 \\
\hline Q10.8—cooperative banks & 1.706 & 1.836 & 1.842 \\
\hline Q10.9—scientific institutions/universities & 1.706 & 2.491 & 2.491 \\
\hline
\end{tabular}

Q11-Question 11 (scale 0 to 10 )

How do you think trust influences the functioning of the collective activity?

$\begin{array}{llll}\text { Q11.1-improves financial results } & 8.059 & 7.727 & 7.719 \\ \text { Q11.2-influences the optimization of the use of resources available to the members of } & 7.588 & 7.836 & 7.825 \\ \text { the organization } & 7.059 & 7.255 & 7.263 \\ \text { Q11.3-optimizes business processes } & 8.294 & 8.673 & 8.649 \\ \text { Q11.4-facilitates teamwork } & 7.706 & 8.000 & 8.000 \\ \text { Q11.5-enables knowledge transfer } & 7.059 & 7.655 & 7.667 \\ \text { Q11.6-enhances entrepreneurial behavior } & 7.765 & 7.818 & 7.807 \\ \text { Q11.7-reduces the risk of failure } & 8.412 & 8.436 & 8.421 \\ \text { Q11.8-strengthens the sense of social identity (belonging to the social environment) } & 8.412 & 8.618 & 8.596 \\ \text { Q11.9-enhances self-esteem and development opportunities } & 9.294 & 8.836 & 8.807 \\ \text { Q11.10-promotes integration } & & \end{array}$

Q13-Question 13 (scale - 5 to 5)

Please assess the impact of the proposed factors on the development of collective entrepreneurship.

\begin{tabular}{|c|c|c|c|}
\hline Q13.1-personality of the leader & 3.765 & 4.236 & 4.246 \\
\hline Q13.2-ability to manage a team by the leader & 4.353 & 4.400 & 4.421 \\
\hline Q13.3—close interpersonal relationships & 3.941 & 4.091 & 4.088 \\
\hline Q13.4 - creativity/resourcefulness of the group & 4.294 & 4.255 & 4.281 \\
\hline Q13.5—focus on achieving a common goal & 4.412 & 4.236 & 4.263 \\
\hline Q13.6-individual risk appetite & 1.824 & 2.400 & 2.456 \\
\hline Q13.7—using talents in the team & 4.471 & 4.455 & 4.474 \\
\hline Q13.8—qualifications of group members & 4.294 & 3.873 & 3.912 \\
\hline Q13.9—family patterns & 3.000 & 3.600 & 3.632 \\
\hline Q13.10— quick and flexible adaptation to changes & 4.118 & 3.964 & 4.000 \\
\hline Q13.11- the climate of social trust & 4.059 & 4.127 & 4.158 \\
\hline Q13.12—the environment & 2.941 & 3.364 & 3.404 \\
\hline Q13.13-access to external financing sources & 3.824 & 3.909 & 3.947 \\
\hline Q13.14-macroeconomic situation & 2.824 & 3.273 & 3.333 \\
\hline Q13.15-legibility and knowledge of legal acts & 3.588 & 3.800 & 3.842 \\
\hline Q13.16-fiscal/tax system & 1.941 & 2.473 & 2.474 \\
\hline Q13.17-access to economic information & 2.824 & 2.964 & 2.947 \\
\hline Q13.18 - condition and development of local technical infrastructure & 3.176 & 3.291 & 3.298 \\
\hline Q13.19—activities of business support institutions & 3.000 & 3.127 & 3.140 \\
\hline Q13.20—activities of local authorities & 3.588 & 3.473 & 3.421 \\
\hline
\end{tabular}

\section{Results and Discussion}

\subsection{Personal and Institutional Trust}

The main question relating to trust is whether one should put trust in someone or something. According to Munns [45], "trust can be defined as a decision to become vulnerable to or dependent on another in return for the possibility of a shared positive outcome". Trust has many levels and dimensions. It is also dynamic and changes over time 
and in different environments. Blomqvist [46] noted that, in psychology, some researchers see trust as a personal trait, while others stress its social aspect. This means that each person has their own predisposition to trust. One can trust another person or a system (an institution). In economics, trust is seen as a mutual trust or "informal agreement" in which an individual or an organization trusts another person or organization that they will act as promised [47-49]. Trust, therefore, is the foundation for building relationships between business partners. However, the very existence of trust inherently entails risk and, consequently, risk is embedded in any entrepreneurial activity [50].

When considering the issue of trust in the context of entrepreneurship, two categories of trust - personal and institutional — need to be distinguished. Personal trust is based on unwritten rules and values that are shared by people in informal relationships. It derives from personal experience in contact with the other party and stimulates further actions according to the assumption of good will of all parties. Institutional trust concerns the relationship between an individual and organizations, as well as formal structures; moreover, apart from generally accepted operating standards, it also has its source in the rules applicable in a given industry or sector. Personal trust is particularly important at the beginning of an entrepreneur's activity on the market. Nevertheless, along with the development of the company, institutional trust also starts playing an important role. In order to perform successfully, an organization needs to have both types of trust [51]. Lack of trust in representatives of various institutions may be a significant obstacle in undertaking entrepreneurial activities.

The literature shows that the higher level of social trust is positively correlated with the level of entrepreneurship [52]. For example, the Japanese trust strangers less compared to the Americans. Managers in collectivist societies (such as Japan) show a lower overall level of trust than their counterparts in individualistic societies (such as the United States) but tend to have more trust in other managers in the same group. According to the research by Ding et al. [53], Turkey has the lowest level of social trust, and Sweden has the highest. Thus, what is the level of trust in the case of Poland? The study of interpersonal trust among the Polish population showed that, despite relatively limited trust in strangers, Poles generally trust people with whom they maintain regular contacts. The vast majority of respondents trust their immediate family $(98 \%)$, their friends $(95 \%)$, extended family $(89 \%)$, people they work with on a daily basis $(88 \%)$, and neighbors $(80 \%)$ [54].

For the purpose of this analysis, we distinguished two types of trust, personal and institutional. A hypothesis was formulated that people operating within the studied forms of collective entrepreneurship in rural areas show more personal than institutional trust.

Personal trust, also known as interpersonal trust, is placed in the people with whom we have close relationships. The most trusted group is usually the family tied by close and intimate relationships, followed by friends and acquaintances, neighbors, coworkers, and business partners, i.e., people we know personally and with whom we interact directly. This type of trust is also placed in people fulfilling specific social and professional roles. In Polish literature, it is referred to as position-related trust [55].

Institutional trust is aimed at institutions and organizations, understood as sets of structural rules within which actions and interactions take place. This group includes schools, universities, the army, churches, courts, the police, banks, stock exchanges, the government, the parliament, and enterprises.

The scale from -5 to 5 , designed to measure trust, allowed the respondents to indicate either the level of existing trust or the lack of it. All the mean scores obtained in questions Q9 and Q10 in the three types of organizations were positive (Table 2). The highest mean score (higher than 4.69) represented trust in family and the loved ones (Q9.1). Interestingly, the next highly trusted groups included friends (Q9.2) and people cooperating in a given organization (Q9.10); the mean score ranged from 3.059 to 3.456. This may indicate that members of rural organizations are also friends. People like the extended family, coworkers, and neighbors (Q9.3, Q9.4, Q9.5, and Q9.7 (for two groups)) received average trust scores of 2.30-3.18. The remaining groups of people from question Q9 and most of institutions 
from question Q10 also received positive mean scores, but at a level closer to the neutral rating. In question Q10, a relatively rating of 2.4-2.9 was given to agricultural advisory centers, i.e., the institutions that implement the mission of supporting the development of rural areas and their residents.

As the survey covered many dimensions, divided into three groups and three subgroups (nine groups in total), principal component analysis was performed to reduce dimensionality. As a result, 19 variants of answers were reduced to first five principal components (Appendix A, Table A5). PC1 explained $25.21 \%$ of the general variance by including variants of trust assessment such as those included in questions Q9.1, Q9.4, Q9.8, Q9.9, Q10.3, and Q10.7. The second component explained 18.94\% of the general variance, including variants of trust assessment such as those included in questions Q9.6, Q9.10, Q10.8, and Q10.9 (Figure 1).

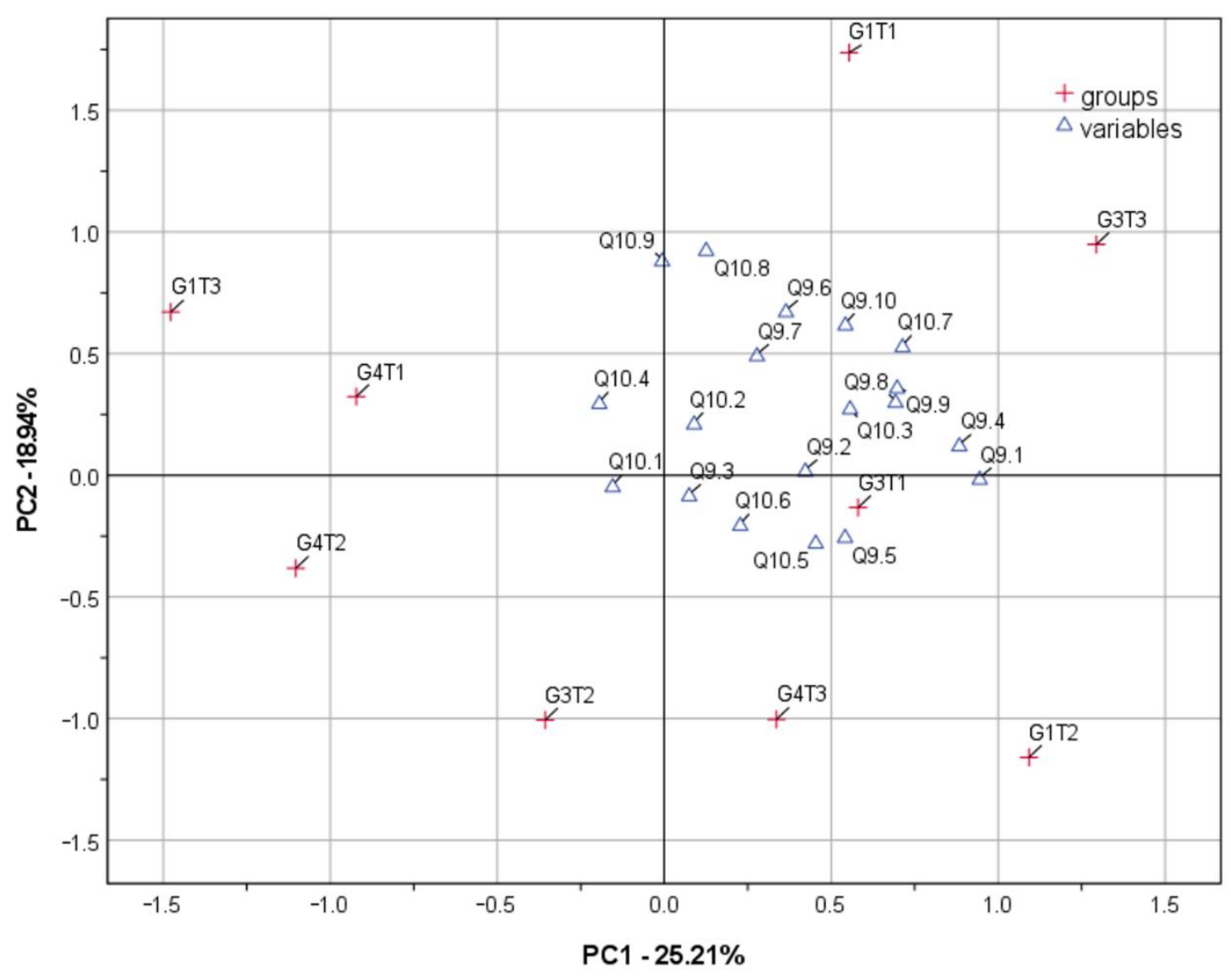

Figure 1. Biplot of relationships of variables (Q9.1, . , Q9.10, Q10.1, . . Q10.9) for groups (G1T1, .. , G1T3, G3T1, .. , G4T3) representing types of organization subdivided according to the declared level of trust in the space of the first two components PC1 and PC2.

The analysis of the results obtained from questions Q9 and Q10 allowed us to positively verify Hypothesis 1, assuming a greater importance of personal trust over institutional trust in the formation and functioning of the studied forms of collective entrepreneurship in rural areas. As our research is one of the few that concerns trust in collective entrepreneurship in rural areas, we can only refer our results to the available analyses carried out as part of the report "2018 Edelman Trust Barometer" [56]. This study showed that the trust in institutions in Poland in 2018 was below global average (the index for Poland was 39/100 compared to the average global index of $48 / 100$ ).

We believe that, in the case of the studied forms of entrepreneurship, these two types of trust are correlated and, therefore, should not be analyzed separately. 


\subsection{Social and Economic Determinants of Collective Entrepreneurship Development}

An attempt was made to evaluate the factors determining the development of collective entrepreneurship. The designed rating scale was from -5 (inhibiting development) through 0 (having no influence) to 5 (stimulating development). Twenty determinants were presented to be evaluated. All determinants obtained average positive scores, which suggests that, according to the respondents, they stimulate the development of collective entrepreneurship in rural areas. The highest mean scores (within the range from 4.00 to 4.65 depending on a group) were achieved by factors related to the leader-personality and managerial skills (Q13.1, Q13.2). Other highly stimulating determinants included working toward a common goal (Q13.5), as well as talents and creativity present in the team (Q13.4, Q13.7), which, in individual groups, were assessed at an average level of 2.94 to 4.42 . The remaining determinants were also assessed positively but depending on the studied group at a lower level (Table 2).

The applied PCA reduced the studied space from 20 dimensions to the first four principal components. PC1 accounted for $37.73 \%$ of the overall variance, concentrating on determinants such as Q13.4, Q13.5, Q13.6, Q13.7, Q13.8, Q13.10, Q13.12, Q13.13, and Q13.20 (Appendix A, Table A6). This group contained high- and medium-rated determinants. The applied varimax rotation revealed that they are mutually correlated. PC2 accounted for $25.62 \%$ of the total variance and the determinants most strongly correlated with it were variables Q13.1, Q13.2, Q13.3, Q13.11, Q13.14, Q13.18, and Q13.19. The first three determinants also had some of the highest ratings. Therefore, this component can be interpreted as gathering the most important features of collective entrepreneurship development (Figure 2). PC 3 accounted for $17.76 \%$ of the overall variance. Determinants related to family patterns (Q13.9), fiscal systems (Q13.16), and the availability of economic information (Q13.17) correlated with it most strongly. Interestingly, PC4 was strongly correlated with only one feature related to the legibility and knowledge of legal acts, and it explained $10.57 \%$ of the overall variance.

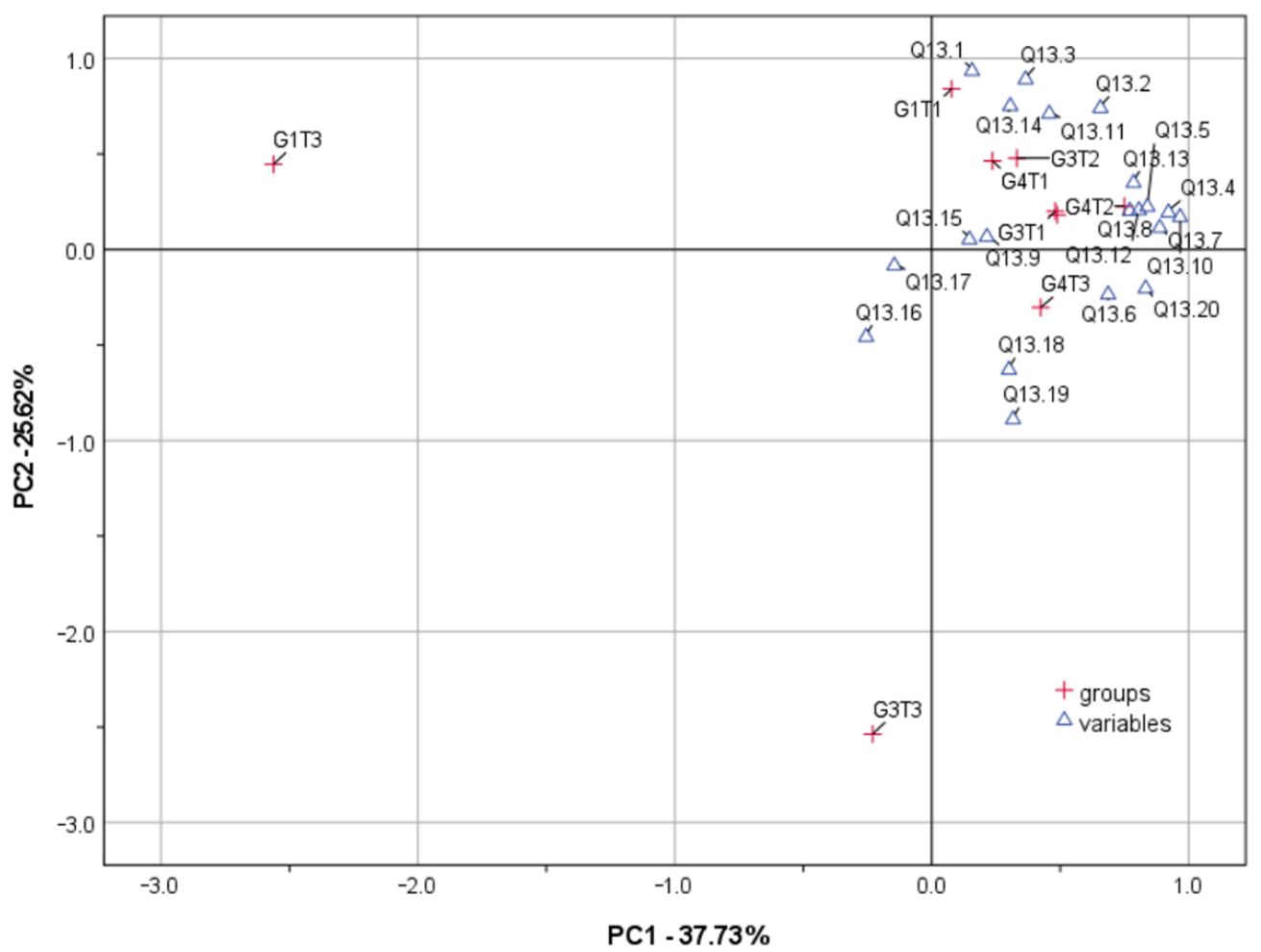

Figure 2. Biplot of relationships of variables (Q13.1, . . , Q13.20) for groups (G1T1, . , G1T3, G3T1, . . G4T3) representing types of organization subdivided according to the declared level of trust in the space of the first two components PC1 and PC2. 
The reduction of 20 initial variables to four principal components enabled explanation in a simplified manner of $91.69 \%$ of the total variance.

The PCA allowed for the positive verification of Hypothesis 2, assuming that social factors determine the functioning of the studied forms of collective entrepreneurship to a greater extent than economic factors.

A significant correlation (at the level of 0.35) was revealed between how the respondents assessed the impact of family relationships, neighborly relations, friendship, and the performance of social roles on the level of trust and the assessment of the importance of social factors influencing the development of collective entrepreneurship (Appendix A, Table A7).

A similar comparative analysis of the impact of social and economic factors on the development of cooperatives was carried out by Pan [57]. This study showed that the influence of social factors on this collective form of entrepreneurship is stronger than of the economic ones. According to Brodziński, the influence of social and economic factors on the development of entrepreneurship among agricultural producers is the same, although the author pointed to creativity, optimism and commitment as the primary drive of entrepreneurship [58]. Furthermore, studies of other researchers indicated a greater impact of these factors on the development of entrepreneurship in rural areas $[59,60]$. According to Björklund, it is easier for entrepreneurs to overcome barriers to innovation if they have specific cognitive abilities. These abilities include sufficient knowledge, access to information, and decision flexibility. Positive attitudes facilitate the implementation of innovations, while negative attitudes make it difficult. A positive attitude toward work and others can enhance individual performance and creativity, foster new relationships, and expand the use of intellectual and social resources [61]. Colombo and Perujo-Villanueva, on the other hand, emphasized that relations between agricultural neighbors are the main determinant of cooperation, not only between small entities [62]. In the research by Krzyżanowska [63] conducted on a group of 132 leaders of agricultural producer groups, trust was assessed as one of the most important interpersonal skills essential in leadership processes. It was rated 3.98 on a Likert scale from 1 to 5 , where 1 meant unimportant and 5 meant very important. The importance of trust in entrepreneurial teams was also confirmed by the results of the research conducted by Falkowski et al. [64] among members of agricultural producer organizations in Poland. In this case, $70 \%$ of the surveyed farmers most often indicated lack of trust as a factor hindering the creation of producer organizations. Only in the case of producer organizations based on family ties was this aspect not so important. This is probably a manifestation of the mentality barrier resulting from the negative experiences of farmers in the times of centrally planned economy and forced collectivization of agricultural sector, which now still influences the preference for private (family) farming. In rural areas in Poland, the generalized trust index is still relatively low compared to larger cities (on a seven-point scale from -3 to +3 , the mean value was -0.88 for rural areas, 0.22 for larger cities, and -0.90 for farmers) [54].

\subsection{Trust in Collective Entrepreneurship}

It was assumed in the study (H3) that, according to the concept of the economics of trust, a higher level of generalized trust would result in a greater trust in various forms of cooperation; furthermore, as participants gain common experiences, the level of trust in group cooperation increases. The analysis performed with the use of descriptive statistics, i.e., the statistics of the distribution of the feature value (location and dispersion) confirmed this hypothesis (H3). The data presented in Figure 3 show that those people who believed that most people could be trusted (T1) (and, therefore, showed a higher level of generalized trust than the remaining respondents) were more likely to trust joint ventures. It is interesting, however, that, regardless of the level of generalized trust, after starting cooperation under the researched forms of entrepreneurship, the trust in the organization visibly increases. The highest increase was recorded in the G3T3 group. The exceptions were respondents representing rural women's circles, who did not define their level of 
trust by indicating the answer "I do not know" (G4T3). In this group, a slight decrease in trust in the circle was noticeable during its operation.

$\mathrm{F}=1.6216, \mathrm{p}=0.03427$

Vertical bars represent + /- standard error

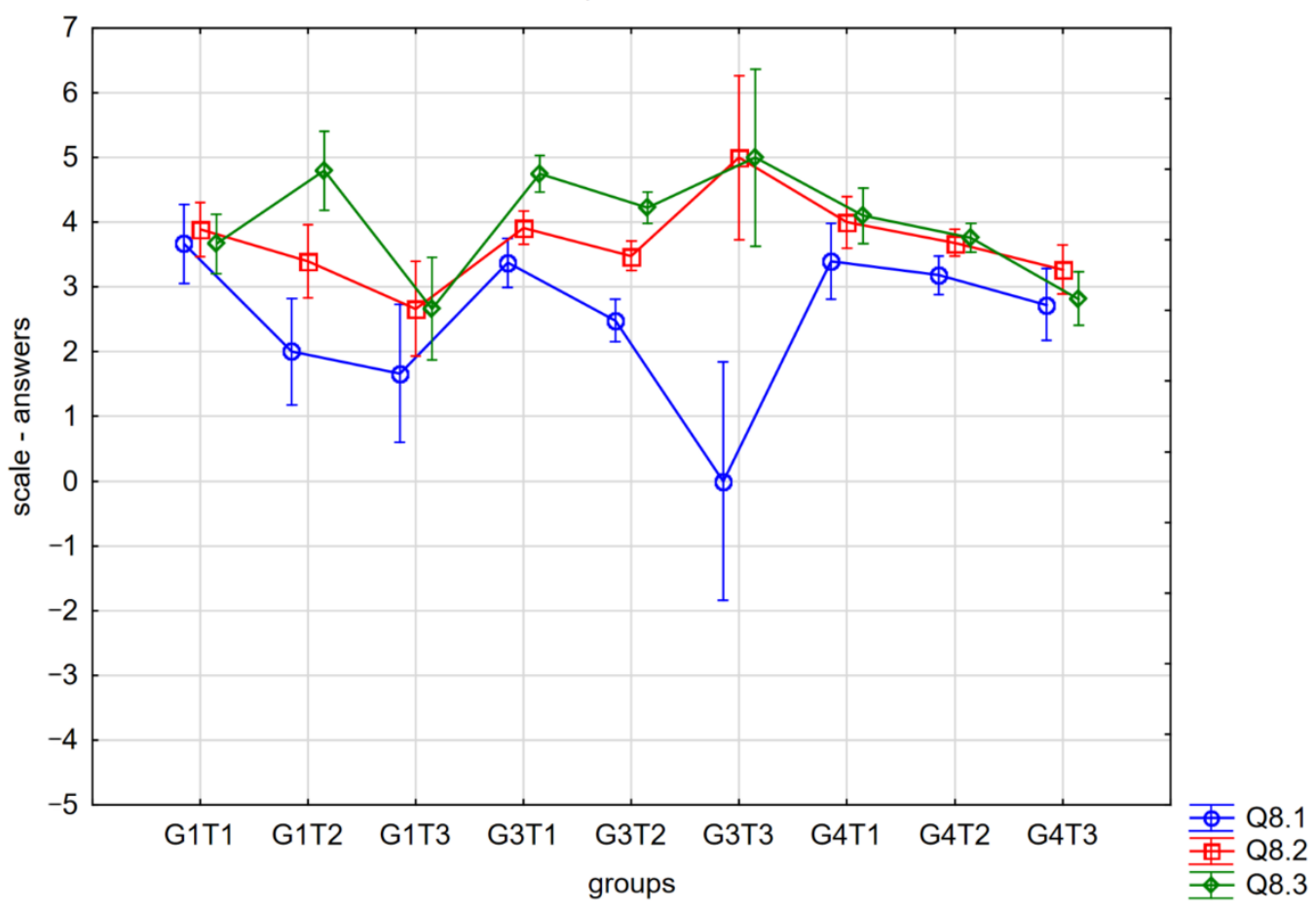

Figure 3. Average trust assessment values (scale from -5 to 5 ) at three stages of participation by organization type. ANOVA at a significance level of 0.05 .

The confirmation of Hypothesis 3 is extremely important from the point of view of the development of collective entrepreneurship in rural areas. Since trust affects the quality of cooperation, it lowers transaction costs and has a positive impact on its durability. In addition, trust can reduce intergroup conflicts and strengthen collaboration between different social groups [53]. This was confirmed by the results of studies by Adro and Franco [65]. The study looked at local and national collaborative networks based on the example of Casa Agrícola dos Arais (CAA). The authors described how a rural farming network operates in a specific sector of Protected Denomination of Origin (PDO) and what its success factors are. Economic benefits, self-confidence, trust, mutual respect, and resilience were the words that the respondents used to identify the factors behind the network's success and the ones that helped them to endure more difficult periods. Despite the fact that the contracts are not formalized, all partners (CAA, milk suppliers, and Tio Careca) had great confidence in the network. On the Likert scale, where 1 meant no trust and 5 meant high trust, all rated the level of trust at 4 or 5 points. Older or less educated producers trusted the given word more than a written contract, which they said they did not need.

The aim of this study was to find an answer to the question whether and to what extent trust affects the functioning of collective entrepreneurship in rural areas. Taking into account the conducted analyses, it can be concluded that trust plays a crucial role, and that the level of trust increases with the length of cooperation.

In Q10, we sought an answer to the question of how, in the respondents' opinion, trust affects the functioning of selected forms of collective activities. Ten aspects that may be affected by trust were selected. The impact was measured on an 11-point scale from 0 (no impact at all) to 10 (very high impact). This scale made it possible to flexibly assess the degree of this impact. All variants of the answers were highly rated by the 
respondents. For individual groups, the mean score was from 7.28 to 8.98 (Table 2). The range of assessment, expressed in the mean values of the answers, was about 1.5, which, on an 11-point scale, can be considered small. PCA was performed, where 10 dimensions were reduced to the first two components which accounted for $85.62 \%$ of the overall variance. PC1 explained $44.89 \%$ of the overall variance and was most strongly correlated with the following response variants: Q11.5, Q11.6, Q11.7, Q11.9, and Q11.10. PC2 explained 40.73\% of the overall variance and was most strongly correlated with the following responses: Q11.1, Q11.2, Q11.3, Q11.4, and Q11.8 (Figure 4).

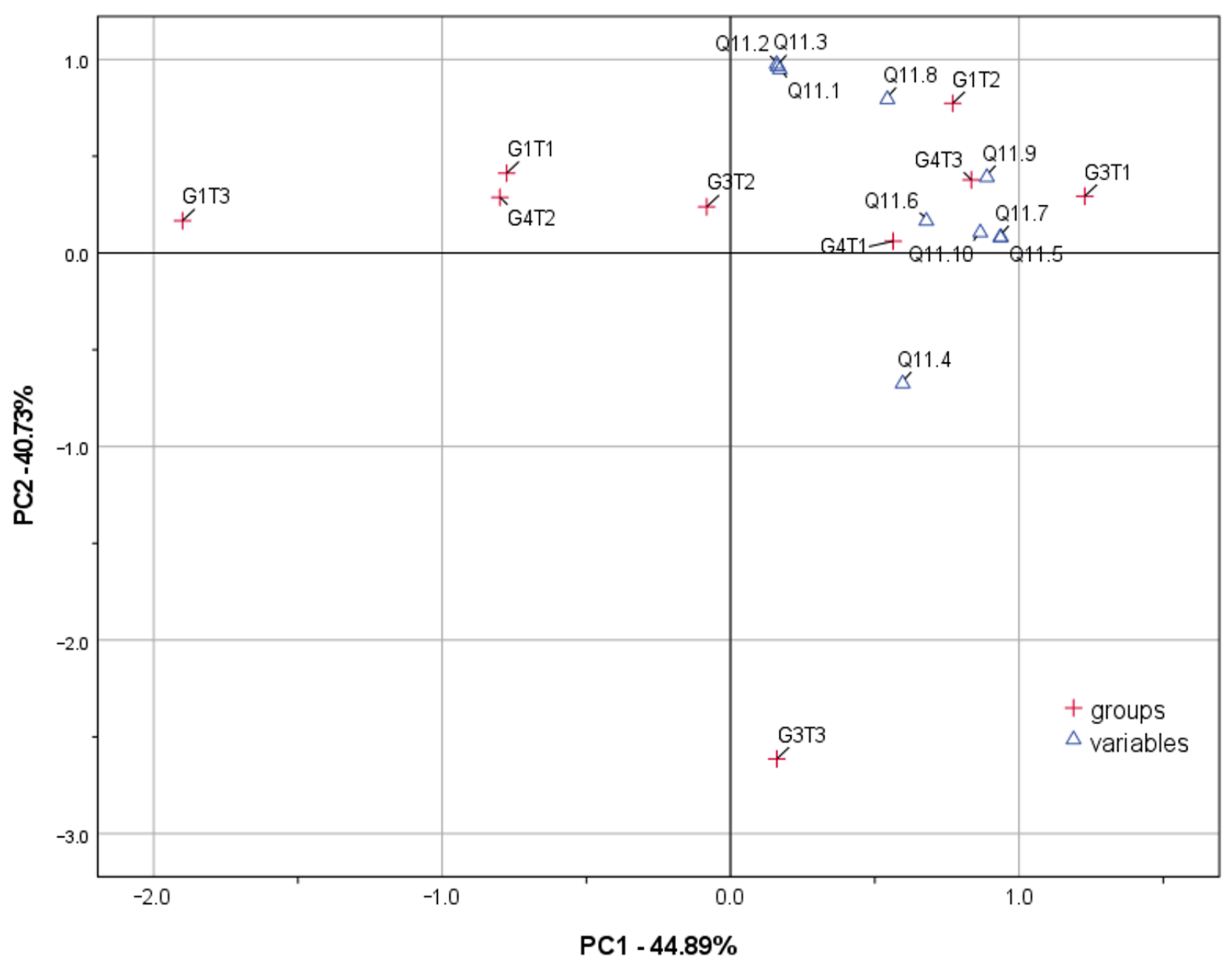

Figure 4. Biplot of relationships of variables $(\mathrm{Q} 11.1, \ldots, \mathrm{Q} 13.10)$ for groups $(\mathrm{G} 1 \mathrm{~T} 1, \ldots, \mathrm{G} 1 \mathrm{~T} 3, \mathrm{G} 3 \mathrm{~T} 1, \ldots, \mathrm{G} 4 \mathrm{~T} 3)$ representing types of organization subdivided according to the declared level of trust in the space of the first two components PC1 and PC2.

The conducted analysis showed that, in the opinion of the respondents, the impact of trust on the functioning of the selected forms of collective entrepreneurship is noticeable in both the economic and the social dimensions. In our study, the respondents rated the impact of trust higher in social areas, such as strengthening the sense of social identity, self-esteem, and development opportunities, as well as a positive impact on teamwork or social integration. The exceptions were people representing the G1T3 group (members of agricultural producer organizations who did not define their level of trust), for whom these aspects were not as important as the economic ones, e.g., improving financial results or optimizing the use of resources. A completely different opinion was expressed by the respondents qualified to the G3T3 group (women from rural women's circles who did 
not define their level of generalized trust), for whom these economic aspects were the least important.

\section{Conclusions}

The development of entrepreneurship in rural areas has been, for many reasons, a more difficult process than in urbanized areas $[7,66]$. This is caused by many factors including location, dispersion, small scale of activity, shallowness of local markets, the level of infrastructure development, and the level of education of rural residents.

Due to the fact that the sample selected for this research was not representative, it does not allow for generalizations. However, as our findings correspond with the results of other authors, as shown in the paper, they provide sufficient grounds for verification of the research hypotheses.

The literature implies that entrepreneurial activity is related to both the most basic trust we place in people with whom we maintain social relations and other types of trust, including trust in institutions. Trust is a value that facilitates cooperation between entrepreneurs and their partners [67-69]. This was confirmed by our research. The conducted PCA showed that the respondents are more likely to trust their family, friends, people they work with, local entrepreneurs, and teachers. In the conducted analysis, institutional trust was rated much lower. The exceptions were agricultural advisory centers, which obtained higher trust mean scores (2.4-2.9) compared to other institutions. This result can be explained by the fact that their activity is directly dedicated to rural residents, and the respondents are familiar with it. Moreover, the PCA analysis revealed that the respondents were also willing to trust institutions such as local authorities, commercial and cooperative banks, and scientific centers. Hypothesis 1 was, thus, confirmed.

The socioeconomic development of rural areas is, inter alia, determined by the effective cooperation between entities operating locally. There is no doubt that the main factor limiting cooperation is insufficient knowledge and, above all, the uncertainty resulting from limited trust. This study shows that trust is a necessary condition for effective cooperation. This was also confirmed by the studies of other researchers [70]. Apart from the influence of trust on the development of collective entrepreneurship, this study shows that other factors, of both a social and an economic nature, also play an important role. The respondents highly rated the impact of social factors including personality traits and skills such as the leader's ability to manage a team, creativity of the members, and orientation toward a common goal. Moreover, conditions such as the climate of trust play an important role. In the opinion of the respondents who actively participate in the analyzed forms of collective entrepreneurship, equally important were economic factors such as the availability of external sources of financing, the macroeconomic situation of the country, the condition of infrastructure, and access to business support institutions. The abovementioned social factors, highly rated by respondents, basically constitute the social capital, which in rural areas is identified mainly with local organizations such as associations, civic groups or producer organizations, rural women's circles, and local action groups covered by this research. Summing up, Hypothesis 2 was positively verified, as the prevalence of social factors over economic factors was demonstrated.

There seems to be a consensus among researchers that a higher level of trust facilitates forming multi-actor networks of entrepreneurs and their successful performance [71,72]. Trust has a considerable impact on cooperation between entrepreneurs in small networks where the relationships are more personal [64]. Our research also shows that people with a higher level of generalized trust are more likely to trust joint ventures, especially before joining a collective endeavor. This confirms Hypothesis 3 . However, a new relationship emerged. The local action group members who did not indicate their level of generalized trust declared that their trust increased with the length of participation. Unfortunately, in the remaining groups, i.e., agricultural producers and rural women's circles, such trust growth was not statistically confirmed. The most surprising results were obtained in the group of people who indicated a low level of generalized trust. In this case, in all 
the studied groups, the level of trust increased along with the length of participation in the organization.

We are aware that our study is one of the first undertaken in this field. The positively verified hypotheses formulated in the research do not, however, justify the formulation of general conclusions. Firstly, to make this possible, further in-depth research would be required in this area, with particular emphasis on the dominant character of the activities typical for different forms of entrepreneurship. Agricultural producer organizations pursue mainly economic goals, while rural women's circles and local action groups focus rather on the social aspects of local community life. Secondly, there was an overrepresentation of women in the sample. This was due to the following reasons: the survey was carried out using the CAWI method, which subjected the process of sampling to a large extent to fate and, despite targeting a diverse population including producer groups, local action groups, rural women's circles, and volunteer fire brigades, responses were obtained mostly from rural women's circles and local action groups represented mainly by women. While our empirical research contributes to the existing literature on trust in collective entrepreneurship in rural areas, it does show some limitations. We believe that the conducted analysis will inspire future research on the role of trust in the development of collective entrepreneurship in rural areas. It seems important to consider the following research areas:

(1) the role of trust in the economics of trust paradigm in the perspective of rural development,

(2) the conditions for the formation and functioning of collective entrepreneurship in rural areas, which is an impulse stimulating the local community to undertake entrepreneurial activity,

(3) defining the factors strengthening the social trust of rural residents.

We hope that the presented research areas will serve as inspiration for future studies. By focusing on trust, this paper contributes to the literature examining the role of trust in the development of collective entrepreneurship in rural areas. Trust is a complex, difficult-to-study topic, both theoretically and methodologically. The limitation of this type of research is the credibility of the respondents in terms of competence and perception. To counteract that, in-depth, qualitative research using the interview technique is required. We believe that our study, which is one of the first in this field, should be seen as a pilot study.

Author Contributions: Conceptualization, L.S., A.J.P. and A.S.; methodology, L.S., A.J.P. and A.S.; formal analysis, L.S., A.J.P. and A.S.; investigation, L.S., A.J.P. and A.S.; writing-original draft preparation, L.S., A.J.P. and A.S.; visualization, L.S. All authors have read and agreed to the published version of the manuscript.

Funding: This research received no external funding.

Institutional Review Board Statement: Not applicable.

Data Availability Statement: Not applicable.

Conflicts of Interest: The authors declare no conflict of interest. 


\section{Appendix A}

Table A1. Pearson's correlation matrix, * significant at the alpha 0.05 level, ${ }^{* *}$ significant at the alpha 0.01 level.

\begin{tabular}{|c|c|c|c|c|c|c|c|c|c|c|c|c|c|c|c|}
\hline & Age & $\begin{array}{l}\text { Years } \\
\text { Partyc }\end{array}$ & Q8.1 & Q8.2 & Q8.3 & Q9.1 & Q9.2 & Q9.3 & Q9.4 & Q9.5 & Q9.6 & Q9.7 & Q9.8 & Q9.9 & Q9.10 \\
\hline age & 1 & $0.301^{* *}$ & 0.058 & 0.108 & 0.113 & 0.036 & -0.006 & 0.013 & 0.027 & 0.067 & 0.067 & 0.024 & 0.105 & 0.114 & 0.110 \\
\hline $\begin{array}{l}\text { years } \\
\text { partyc }\end{array}$ & $0.301^{* *}$ & 1 & -0.062 & -0.120 & 0.138 & 0.137 & 0.115 & -0.017 & -0.050 & 0.036 & 0.038 & -0.021 & 0.032 & 0.071 & 0.090 \\
\hline Q8.1 & 0.058 & -0.062 & 1 & $0.540^{* *}$ & 0.079 & 0.026 & $0.279 * *$ & 0.200 * & 0.008 & $0.192 *$ & -0.007 & $0.233^{* *}$ & $0.315^{* *}$ & $0.273^{* *}$ & 0.138 \\
\hline Q8.2 & 0.108 & -0.120 & $0.540 * *$ & 1 & 0.208 * & 0.015 & 0.166 & 0.212 * & 0.100 & 0.220 * & 0.059 & $0.240^{* *}$ & $0.353^{* *}$ & $0.261^{* *}$ & $0.224^{* *}$ \\
\hline Q8.3 & 0.113 & 0.138 & 0.079 & $0.208^{*}$ & 1 & 0.005 & -0.005 & -0.012 & 0.127 & 0.141 & -0.024 & 0.158 & 0.220 * & 0.195 * & $0.419^{* *}$ \\
\hline Q9.1 & 0.036 & 0.137 & 0.026 & 0.015 & 0.005 & 1 & $0.416^{* *}$ & $0.331^{* *}$ & 0.185 * & 0.111 & -0.035 & 0.138 & 0.145 & 0.111 & 0.068 \\
\hline Q9.3 & 0.013 & -0.017 & $0.200 *$ & 0.212 * & -0.012 & $0.331^{* *}$ & $0.670^{* *}$ & 1 & $0.401^{* *}$ & $0.445^{* *}$ & $0.277^{* *}$ & $0.486^{* *}$ & $0.498^{* *}$ & $0.477^{* *}$ & $0.236^{* *}$ \\
\hline Q9.4 & 0.027 & -0.050 & 0.008 & 0.100 & 0.127 & $0.185^{*}$ & $0.345^{* *}$ & $0.401^{* *}$ & 1 & $0.442^{* *}$ & $0.312 * *$ & $0.251^{* *}$ & $0.298^{* *}$ & $0.300^{* *}$ & $0.345^{* *}$ \\
\hline Q9.5 & 0.067 & 0.036 & 0.192 * & 0.220 * & 0.141 & 0.111 & $0.440 * *$ & $0.445^{* *}$ & $0.442 * *$ & 1 & $0.503^{* *}$ & $0.390 * *$ & $0.506^{* *}$ & $0.435^{* *}$ & 0.372 ** \\
\hline Q99.6 & 0.067 & 0.038 & -0.007 & 0.059 & -0.024 & -0.035 & 0.206 * & $0.277^{* *}$ & $0.312^{* *}$ & $0.503^{* *}$ & 1 & $0.375^{* *}$ & $0.455^{* *}$ & $0.501^{* *}$ & $0.228^{* *}$ \\
\hline Q9.7 & 0.024 & -0.021 & $0.233^{* *}$ & $0.240^{* *}$ & 0.158 & 0.138 & $0.373^{* *}$ & $0.486^{* *}$ & $0.251 * *$ & $0.390^{* *}$ & $0.375^{* *}$ & 1 & $0.738^{* *}$ & $0.597^{* *}$ & $0.423^{* *}$ \\
\hline Q9.8 & 0.105 & 0.032 & $0.315^{* *}$ & $0.353^{* *}$ & 0.220 * & 0.145 & $0.456^{* *}$ & $0.498^{* *}$ & $0.298^{* *}$ & $0.506^{* *}$ & $0.455^{* *}$ & $0.738^{* *}$ & 1 & 0.722 ** & $0.467^{* *}$ \\
\hline Q9.9 & 0.114 & 0.071 & $0.273^{* *}$ & $0.261^{* *}$ & 0.195 * & 0.111 & $0.392 * *$ & $0.477^{* *}$ & $0.300 * *$ & $0.435 * *$ & $0.501^{* *}$ & $0.597^{* *}$ & $0.722^{* *}$ & 1 & $0.370^{* *}$ \\
\hline Q9.10 & 0.110 & 0.090 & 0.138 & $0.224^{* *}$ & $0.419^{* *}$ & 0.068 & $0.305^{* *}$ & $0.236^{* *}$ & $0.345^{* *}$ & 0.372 ** & $0.228^{* *}$ & $0.423^{* *}$ & $0.467^{* *}$ & $0.370^{* *}$ & 1 \\
\hline Q10.1 & -0.005 & 0.072 & 0.155 & 0.143 & -0.067 & 0.006 & 0.178 * & 0.093 & 0.046 & 0.189 * & 0.125 & 0.099 & 0.200 * & 0.145 & $0.243^{* *}$ \\
\hline Q10.3 & 0.049 & 0.045 & 0.157 & $0.261^{* *}$ & 0.154 & $0.177^{*}$ & $0.248^{* *}$ & $0.205^{*}$ & 0.210 * & $0.292 * *$ & 0.203 * & $0.372 * *$ & $0.439 * *$ & $0.327^{* *}$ & $0.304^{* *}$ \\
\hline Q10.4 & -0.001 & 0.071 & 0.160 & 0.076 & -0.063 & 0.133 & $0.234^{* *}$ & $0.264^{* *}$ & 0.088 & $0.273^{* *}$ & 0.194 * & $0.268^{* *}$ & $0.365^{* *}$ & $0.284^{* *}$ & $0.295^{* *}$ \\
\hline Q10.5 & -0.062 & 0.099 & 0.220 * & $0.272^{* *}$ & 0.111 & 0.077 & $0.308^{* *}$ & $0.242 * *$ & $0.201 *$ & $0.402^{* *}$ & $0.231 * *$ & $0.287^{* *}$ & $0.544^{* *}$ & $0.318^{* *}$ & 0.228 ** \\
\hline Q10.6 & -0.054 & 0.108 & 0.071 & 0.176 * & 0.131 & 0.109 & $0.270 * *$ & $0.237^{* *}$ & $0.295^{* *}$ & $0.290 * *$ & $0.175^{*}$ & 0.339 ** & $0.416^{* *}$ & $0.278^{* *}$ & 0.312 ** \\
\hline Q10.7 & 0.042 & 0.048 & 0.010 & 0.084 & 0.101 & $0.238^{* *}$ & $0.334^{* *}$ & 0.302 ** & $0.266^{* *}$ & $0.254^{* *}$ & 0.161 & $0.294^{* *}$ & $0.428^{* *}$ & $0.403^{* *}$ & $0.355^{* *}$ \\
\hline Q10.8 & 0.125 & 0.170 & -0.033 & 0.083 & 0.031 & $0.179 *$ & $0.238^{* *}$ & $0.265^{* *}$ & 0.112 & $0.242^{* *}$ & $0.254^{* *}$ & $0.299^{* *}$ & $0.360^{* *}$ & $0.368^{* *}$ & $0.256^{* *}$ \\
\hline Q10.9 & 0.029 & 0.067 & 0.082 & 0.168 & 0.126 & 0.027 & $0.263^{* *}$ & $0.210 *$ & $0.257^{* *}$ & $0.243^{* *}$ & $0.230^{* *}$ & $0.313^{* *}$ & $0.331^{* *}$ & $0.294^{* *}$ & 0.339 ** \\
\hline Q11.1 & -0.156 & $-0.281^{* *}$ & 0.142 & 0.010 & -0.026 & 0.078 & $0.288^{* *}$ & $0.309 * *$ & 0.067 & 0.138 & $0.187^{*}$ & 0.153 & 0.122 & 0.156 & 0.113 \\
\hline Q11.2 & -0.147 & $-0.211 *$ & 0.066 & -0.034 & 0.063 & -0.019 & $0.225^{* *}$ & 0.250 ** & 0.051 & 0.155 & 0.181 * & 0.223 * & 0.177 * & 0.162 & $0.270^{* *}$ \\
\hline Q11.3 & -0.128 & $-0.328^{* *}$ & 0.024 & -0.055 & 0.103 & -0.110 & 0.093 & 0.174 * & 0.023 & 0.060 & 0.065 & 0.106 & 0.115 & 0.104 & 0.146 \\
\hline Q11.4 & -0.193 * & $-0.254^{* *}$ & -0.053 & -0.050 & -0.002 & 0.050 & $0.253^{* *}$ & $0.224^{* *}$ & 0.137 & 0.211 * & 0.184 * & $0.222 *$ & 0.143 & 0.137 & $0.241^{* *}$ \\
\hline Q11.5 & -0.190 * & -0.161 & -0.039 & -0.009 & 0.025 & 0.111 & $0.257^{* *}$ & $0.258^{* *}$ & 0.154 & 0.135 & 0.081 & $0.237^{* *}$ & 0.195 * & $0.239^{* *}$ & $0.236^{* *}$ \\
\hline Q11.6 & -0.127 & $-0.205^{*}$ & 0.028 & 0.013 & 0.028 & 0.104 & $0.317^{* *}$ & $0.343^{* *}$ & 0.201 * & $0.188^{*}$ & 0.157 & $0.318^{* *}$ & $0.269^{* *}$ & $0.281^{* *}$ & 0.222 * \\
\hline Q11.7 & -0.059 & $-0.234^{* *}$ & 0.159 & 0.166 & 0.102 & 0.093 & $0.273^{* *}$ & 0.270 ** & 0.148 & 0.143 & 0.112 & $0.217^{*}$ & 0.126 & 0.157 & $0.246^{* *}$ \\
\hline
\end{tabular}


Table A1. Cont.

\begin{tabular}{|c|c|c|c|c|c|c|c|c|c|c|c|c|c|c|c|}
\hline & Age & $\begin{array}{l}\text { Years } \\
\text { Partyc }\end{array}$ & Q8.1 & Q8.2 & Q8.3 & Q9.1 & Q9.2 & Q9.3 & Q9.4 & Q9.5 & Q9.6 & Q9.7 & Q9.8 & Q9.9 & Q9.10 \\
\hline Q11.8 & 0.024 & -0.106 & 0.095 & 0.050 & 0.105 & -0.026 & $0.222 *$ & 0.136 & 0.053 & 0.195 * & 0.123 & $0.208^{*}$ & $0.191 *$ & 0.163 & $0.227^{* *}$ \\
\hline Q11.9 & 0.016 & -0.069 & 0.161 & 0.096 & 0.099 & 0.059 & $0.287^{* *}$ & $0.233^{* *}$ & 0.086 & 0.180 * & 0.105 & $0.241^{* *}$ & $0.229^{* *}$ & $0.239^{* *}$ & 0.270 ** \\
\hline Q13.1 & 0.134 & -0.146 & 0.092 & 0.040 & 0.022 & 0.085 & $0.233^{* *}$ & 0.118 & 0.052 & 0.204 * & 0.187 * & $0.260^{* *}$ & $0.226^{* *}$ & 0.179 * & 0.140 \\
\hline Q13.2 & 0.140 & -0.042 & 0.154 & 0.164 & 0.075 & $0.319^{* *}$ & $0.260^{* *}$ & 0.180 * & 0.062 & $0.173 *$ & 0.157 & $0.250^{* *}$ & $0.267^{* *}$ & $0.265^{* *}$ & 0.124 \\
\hline Q13.3 & 0.152 & 0.073 & 0.117 & 0.079 & 0.160 & 0.074 & 0.089 & 0.039 & 0.114 & $0.290 * *$ & $0.212 *$ & 0.126 & 0.163 & 0.161 & 0.159 \\
\hline Q13.4 & 0.098 & -0.032 & 0.064 & 0.154 & 0.089 & 0.042 & 0.064 & 0.046 & 0.142 & 0.173 * & 0.107 & 0.078 & 0.164 & 0.105 & 0.016 \\
\hline Q13.6 & -0.036 & -0.093 & $0.187^{*}$ & $0.337^{* *}$ & $0.256^{* *}$ & 0.017 & 0.048 & 0.122 & $0.226^{* *}$ & 0.113 & 0.040 & 0.191 * & $0.221 *$ & 0.183 * & 0.182 * \\
\hline Q13.7 & 0.102 & 0.002 & 0.086 & 0.144 & 0.180 * & 0.048 & -0.012 & 0.049 & -0.068 & 0.032 & -0.018 & 0.116 & 0.141 & 0.161 & -0.011 \\
\hline Q13.8 & 0.158 & -0.057 & 0.063 & 0.098 & 0.082 & 0.065 & 0.063 & 0.041 & -0.080 & 0.069 & 0.111 & 0.113 & 0.097 & $0.182 *$ & 0.098 \\
\hline Q13.9 & 0.141 & 0.094 & $0.224^{* *}$ & $0.245^{* *}$ & 0.121 & 0.197 * & $0.255^{* *}$ & $0.331^{* *}$ & 0.010 & 0.312 ** & $0.231^{* *}$ & $0.312^{* *}$ & $0.359 * *$ & $0.328^{* *}$ & 0.203 * \\
\hline Q13.10 & 0.094 & -0.113 & $0.249^{* *}$ & $0.279^{* *}$ & 0.102 & 0.158 & $0.220 *$ & $0.253^{* *}$ & 0.105 & 0.143 & 0.077 & $0.266^{* *}$ & $0.313^{* *}$ & $0.283^{* *}$ & 0.141 \\
\hline Q13.11 & 0.172 * & -0.035 & 0.190 * & 0.209 * & 0.107 & 0.015 & 0.136 & 0.079 & -0.110 & 0.193 * & 0.099 & $0.235^{* *}$ & $0.284^{* *}$ & 0.208 * & 0.179 * \\
\hline Q13.12 & -0.010 & 0.085 & 0.221 * & $0.196^{*}$ & 0.087 & 0.187 * & 0.192 * & 0.109 & 0.106 & 0.189 * & 0.112 & 0.194 * & $0.275^{* *}$ & $0.273 * *$ & 0.054 \\
\hline Q13.13 & 0.155 & -0.042 & 0.170 & 0.130 & 0.023 & 0.115 & 0.192 * & 0.155 & 0.087 & 0.073 & 0.048 & 0.222 * & $0.257^{* *}$ & $0.285^{* *}$ & 0.061 \\
\hline Q13.14 & 0.171 & 0.168 & $0.249^{* *}$ & 0.151 & -0.018 & 0.140 & 0.148 & 0.071 & 0.052 & 0.020 & -0.055 & 0.133 & 0.206 * & 0.194 * & 0.028 \\
\hline Q13.16 & 0.087 & -0.025 & 0.076 & 0.184 * & 0.078 & 0.040 & 0.147 & 0.211 * & 0.139 & 0.260 ** & 0.077 & $0.229 * *$ & $0.359^{* *}$ & 0.353 ** & $0.249^{* *}$ \\
\hline Q13.17 & 0.079 & -0.044 & 0.050 & 0.167 & 0.029 & 0.129 & $0.208^{*}$ & $0.206^{*}$ & 0.149 & 0.205 * & 0.058 & $0.204^{*}$ & $0.288^{* *}$ & $0.275^{* *}$ & 0.136 \\
\hline Q13.18 & 0.055 & -0.051 & 0.136 & 0.149 & 0.048 & $0.176^{*}$ & $0.276^{* *}$ & 0.215 * & 0.011 & 0.116 & 0.048 & $0.252^{* *}$ & $0.315^{* *}$ & 0.330 ** & 0.164 \\
\hline Q13.19 & 0.025 & -0.100 & 0.048 & 0.150 & -0.007 & $0.249^{* *}$ & $0.355^{* *}$ & $0.348^{* *}$ & 0.181 * & 0.168 & 0.106 & $0.319^{* *}$ & $0.376^{* *}$ & $0.381^{* *}$ & 0.172 * \\
\hline Q13.20 & 0.010 & -0.037 & 0.016 & -0.006 & 0.043 & 0.033 & 0.105 & 0.129 & -0.093 & 0.040 & 0.055 & 0.160 & $0.219 *$ & 0.196 * & -0.025 \\
\hline
\end{tabular}

Table A2. Pearson's correlation matrix, ${ }^{*}$ significant at the alpha 0.05 level, ${ }^{* *}$ significant at the alpha 0.01 level.

\begin{tabular}{|c|c|c|c|c|c|c|c|c|c|c|c|c|c|c|c|}
\hline & Q10.1 & Q10.2 & Q10.3 & Q10.4 & Q10.5 & Q10.6 & Q10.7 & Q10.8 & Q10.9 & Q11.1 & Q11.2 & Q11.3 & Q11.4 & Q11.5 & Q11.6 \\
\hline age & -0.005 & 0.035 & 0.049 & -0.001 & -0.062 & -0.054 & 0.042 & 0.125 & 0.029 & -0.156 & -0.147 & -0.128 & $-0.193 *$ & $-0.190 *$ & -0.127 \\
\hline $\begin{array}{c}\text { years } \\
\text { partyc }\end{array}$ & 0.072 & -0.049 & 0.045 & 0.071 & 0.099 & 0.108 & 0.048 & 0.170 & 0.067 & $-0.281^{* *}$ & -0.211 * & -0.328 ** & $-0.254^{* *}$ & -0.161 & $-0.205^{*}$ \\
\hline Q8.2 & 0.143 & 0.174 * & $0.261^{* *}$ & 0.076 & $0.272^{* *}$ & $0.176^{*}$ & 0.084 & 0.083 & 0.168 & 0.010 & -0.034 & -0.055 & -0.050 & -0.009 & 0.013 \\
\hline Q8.3 & -0.067 & 0.022 & 0.154 & -0.063 & 0.111 & 0.131 & 0.101 & 0.031 & 0.126 & -0.026 & 0.063 & 0.103 & -0.002 & 0.025 & 0.028 \\
\hline Q9.1 & 0.006 & 0.145 & $0.177^{*}$ & 0.133 & 0.077 & 0.109 & $0.238^{* *}$ & 0.179 * & 0.027 & 0.078 & -0.019 & -0.110 & 0.050 & 0.111 & 0.104 \\
\hline Q9.2 & 0.178 * & $0.235^{* *}$ & $0.248^{* *}$ & $0.234^{* *}$ & $0.308^{* *}$ & 0.270 ** & $0.334^{* *}$ & $0.238^{* *}$ & $0.263^{* *}$ & $0.288^{* *}$ & $0.225^{* *}$ & 0.093 & $0.253^{* *}$ & $0.257^{* *}$ & $0.317^{* *}$ \\
\hline
\end{tabular}


Table A2. Cont.

\begin{tabular}{|c|c|c|c|c|c|c|c|c|c|c|c|c|c|c|c|}
\hline & Q10.1 & Q10.2 & Q10.3 & Q10.4 & Q10.5 & Q10.6 & Q10.7 & Q10.8 & Q10.9 & Q11.1 & Q11.2 & Q11.3 & Q11.4 & Q11.5 & Q11.6 \\
\hline Q9.3 & 0.093 & $0.322^{* *}$ & $0.205^{*}$ & $0.264^{* *}$ & $0.242^{* *}$ & $0.237^{* *}$ & 0.302 ** & $0.265^{* *}$ & $0.210 *$ & $0.309 * *$ & $0.250 * *$ & 0.174 * & $0.224^{* *}$ & $0.258^{* *}$ & $0.343^{* *}$ \\
\hline Q9.4 & 0.046 & 0.217 * & 0.210 * & 0.088 & 0.201 * & $0.295^{* *}$ & $0.266^{* *}$ & 0.112 & $0.257^{* *}$ & 0.067 & 0.051 & 0.023 & 0.137 & 0.154 & 0.201 * \\
\hline Q9.5 & 0.189 * & $0.283^{* *}$ & $0.292 * *$ & $0.273^{* *}$ & $0.402 * *$ & 0.290 ** & 0.254 ** & $0.242^{* *}$ & 0.243 ** & 0.138 & 0.155 & 0.060 & 0.211 * & 0.135 & 0.188 * \\
\hline Q9.7 & 0.099 & $0.275^{* *}$ & $0.372^{* *}$ & $0.268^{* *}$ & $0.287^{* *}$ & $0.339 * *$ & $0.294^{* *}$ & $0.299 * *$ & $0.313^{* *}$ & 0.153 & $0.223 *$ & 0.106 & $0.222 *$ & $0.237^{* *}$ & $0.318^{* *}$ \\
\hline Q9.8 & 0.200 * & $0.439^{* *}$ & 0.439 ** & $0.365^{* *}$ & $0.544^{* *}$ & $0.416^{* *}$ & $0.428^{* *}$ & 0.360 ** & 0.331 ** & 0.122 & 0.177 * & 0.115 & 0.143 & 0.195 * & $0.269^{* *}$ \\
\hline Q9.9 & 0.145 & $0.362^{* *}$ & $0.327^{* *}$ & $0.284^{* *}$ & $0.318^{* *}$ & $0.278^{* *}$ & $0.403^{* *}$ & $0.368^{* *}$ & $0.294^{* *}$ & 0.156 & 0.162 & 0.104 & 0.137 & $0.239^{* *}$ & $0.281^{* *}$ \\
\hline Q9.10 & $0.243^{* *}$ & $0.228^{* *}$ & $0.304^{* *}$ & $0.295^{* *}$ & $0.228^{* *}$ & $0.312^{* *}$ & $0.355^{* *}$ & $0.256^{* *}$ & $0.339^{* *}$ & 0.113 & $0.270^{* *}$ & 0.146 & $0.241^{* *}$ & $0.236^{* *}$ & 0.222 * \\
\hline Q10.2 & $0.507^{* *}$ & 1 & $0.310^{* *}$ & $0.424 * *$ & $0.455^{* *}$ & $0.312^{* *}$ & $0.462 * *$ & $0.394^{* *}$ & $0.269 * *$ & $0.224^{* *}$ & 0.044 & 0.100 & -0.009 & -0.060 & 0.086 \\
\hline Q10.3 & $0.318^{* *}$ & $0.310^{* *}$ & 1 & $0.464^{* *}$ & $0.434^{* *}$ & $0.421^{* *}$ & $0.476^{* *}$ & $0.448^{* *}$ & $0.404^{* *}$ & 0.093 & 0.115 & 0.057 & 0.135 & 0.088 & 0.025 \\
\hline Q10.4 & $0.471^{* *}$ & $0.424^{* *}$ & $0.464^{* *}$ & 1 & $0.514^{* *}$ & $0.504^{* *}$ & $0.427^{* *}$ & $0.421^{* *}$ & $0.376^{* *}$ & $0.244^{* *}$ & 0.128 & 0.020 & 0.107 & 0.100 & 0.056 \\
\hline Q10.5 & $0.385^{* *}$ & $0.455^{* *}$ & $0.434^{* *}$ & $0.514^{* *}$ & 1 & $0.669^{* *}$ & $0.426^{* *}$ & $0.418^{* *}$ & $0.459 * *$ & 0.163 & 0.099 & 0.104 & 0.058 & 0.141 & 0.118 \\
\hline Q10.6 & $0.341^{* *}$ & $0.312^{* *}$ & $0.421 * *$ & $0.504^{* *}$ & $0.669^{* *}$ & 1 & $0.532 * *$ & $0.386^{* *}$ & $0.506^{* *}$ & 0.159 & 0.153 & 0.105 & 0.111 & 0.195 * & 0.113 \\
\hline Q10.7 & $0.292^{* *}$ & $0.462^{* *}$ & $0.476^{* *}$ & $0.427^{* *}$ & $0.426^{* *}$ & $0.532 * *$ & 1 & $0.713^{* *}$ & $0.490^{* *}$ & 0.179 * & $0.230 * *$ & 0.147 & 0.160 & 0.201 * & $0.249^{* *}$ \\
\hline Q10.8 & $0.367^{* *}$ & $0.394^{* *}$ & $0.448^{* *}$ & $0.421^{* *}$ & $0.418^{* *}$ & $0.386^{* *}$ & $0.713^{* *}$ & 1 & $0.610^{* *}$ & 0.109 & 0.156 & 0.035 & 0.143 & 0.092 & 0.150 \\
\hline Q10.9 & $0.323^{* *}$ & $0.269^{* *}$ & $0.404^{* *}$ & $0.376^{* *}$ & $0.459^{* *}$ & $0.506^{* *}$ & $0.490^{* *}$ & $0.610^{* *}$ & 1 & 0.170 & $0.309^{* *}$ & 0.161 & $0.298^{* *}$ & $0.274^{* *}$ & $0.255^{* *}$ \\
\hline Q11.1 & 0.301 ** & $0.224^{* *}$ & 0.093 & $0.244^{* *}$ & 0.163 & 0.159 & 0.179 * & 0.109 & 0.170 & 1 & $0.685^{* *}$ & $0.702^{* *}$ & $0.483^{* *}$ & $0.493^{* *}$ & $0.550^{* *}$ \\
\hline Q11.3 & 0.055 & 0.100 & 0.057 & 0.020 & 0.104 & 0.105 & 0.147 & 0.035 & 0.161 & 0.702 ** & 0.793 ** & 1 & $0.645^{* *}$ & $0.641^{* *}$ & $0.657^{* *}$ \\
\hline Q11.4 & 0.007 & -0.009 & 0.135 & 0.107 & 0.058 & 0.111 & 0.160 & 0.143 & $0.298^{* *}$ & $0.483^{* *}$ & $0.715^{* *}$ & $0.645^{* *}$ & 1 & $0.796^{* *}$ & $0.731^{* *}$ \\
\hline Q11.5 & -0.003 & -0.060 & 0.088 & 0.100 & 0.141 & 0.195 * & 0.201 * & 0.092 & $0.274^{* *}$ & $0.493^{* *}$ & $0.691^{* *}$ & $0.641^{* *}$ & $0.796^{* *}$ & 1 & $0.829^{* *}$ \\
\hline Q11.6 & 0.026 & 0.086 & 0.025 & 0.056 & 0.118 & 0.113 & $0.249 * *$ & 0.150 & $0.255^{* *}$ & 0.550 ** & $0.707^{* *}$ & $0.657^{* *}$ & $0.731^{* *}$ & $0.829 * *$ & 1 \\
\hline Q11.7 & 0.033 & 0.025 & 0.078 & 0.091 & 0.070 & 0.160 & 0.128 & 0.117 & $0.237^{* *}$ & 0.601 ** & $0.661^{* *}$ & 0.579 ** & $0.644^{* *}$ & $0.629^{* *}$ & $0.655^{* *}$ \\
\hline Q11.8 & 0.112 & -0.003 & 0.100 & 0.022 & 0.058 & 0.080 & 0.137 & 0.105 & 0.189 * & $0.436^{* *}$ & 0.602 ** & 0.502 ** & $0.704^{* *}$ & 0.609 ** & $0.586^{* *}$ \\
\hline Q11.9 & 0.045 & -0.061 & 0.115 & 0.098 & 0.068 & 0.139 & 0.146 & 0.119 & $0.274^{* *}$ & $0.407^{* *}$ & $0.574^{* *}$ & $0.443^{* *}$ & $0.679^{* *}$ & $0.708^{* *}$ & $0.642 * *$ \\
\hline Q11.10 & -0.015 & -0.029 & 0.180 * & 0.099 & 0.125 & 0.193 * & 0.174 * & 0.136 & 0.147 & $0.296^{* *}$ & $0.424^{* *}$ & $0.396^{* *}$ & $0.551^{* *}$ & $0.546^{* *}$ & $0.428^{* *}$ \\
\hline Q13.1 & 0.074 & 0.131 & 0.140 & 0.167 & 0.005 & 0.091 & 0.164 & 0.108 & 0.196 * & $0.334^{* *}$ & $0.433^{* *}$ & $0.293^{* *}$ & $0.470^{* *}$ & $0.294^{* *}$ & $0.303^{* *}$ \\
\hline Q13.2 & 0.050 & 0.071 & 0.132 & $0.202 *$ & 0.076 & 0.101 & 0.204 * & 0.120 & 0.159 & $0.307^{* *}$ & $0.307^{* *}$ & $0.203^{*}$ & $0.345^{* *}$ & $0.337^{* *}$ & $0.292 * *$ \\
\hline Q13.3 & 0.139 & 0.205 * & 0.113 & $0.352^{* *}$ & 0.138 & $0.251 * *$ & $0.224 * *$ & 0.165 & 0.195 * & $0.343^{* *}$ & $0.232 * *$ & 0.144 & $0.226^{* *}$ & 0.191 * & 0.153 \\
\hline Q13.4 & 0.059 & 0.095 & 0.116 & 0.130 & 0.171 * & 0.171 * & 0.088 & 0.011 & 0.079 & $0.206^{*}$ & $0.200 *$ & $0.232^{* *}$ & $0.245^{* *}$ & 0.212 * & 0.151 \\
\hline Q13.5 & -0.037 & 0.036 & 0.051 & 0.036 & 0.093 & 0.120 & 0.093 & -0.005 & 0.014 & $0.238^{* *}$ & 0.205 * & $0.243^{* *}$ & $0.224^{* *}$ & $0.265^{* *}$ & $0.262^{* *}$ \\
\hline Q13.6 & -0.061 & 0.142 & $0.176^{*}$ & 0.191 * & 0.145 & 0.179 * & 0.158 & 0.019 & $0.216^{*}$ & $0.300^{* *}$ & 0.210 * & $0.287^{* *}$ & 0.107 & $0.231^{* *}$ & $0.252^{* *}$ \\
\hline Q13.7 & -0.057 & -0.030 & 0.017 & 0.140 & -0.018 & 0.018 & 0.002 & -0.046 & -0.057 & 0.209 * & 0.261 ** & 0.220 * & $0.225^{* *}$ & $0.257^{* *}$ & 0.185 * \\
\hline Q13.8 & -0.035 & 0.125 & 0.155 & 0.056 & -0.138 & -0.109 & -0.002 & -0.064 & -0.133 & $0.176^{*}$ & 0.151 & 0.196 * & 0.213 * & 0.121 & 0.037 \\
\hline Q13.9 & 0.107 & $0.254^{* *}$ & 0.217 * & $0.369^{* *}$ & $0.172 *$ & 0.209 * & -0.003 & 0.079 & 0.015 & 0.156 & 0.095 & 0.047 & 0.144 & 0.114 & 0.044 \\
\hline Q13.10 & 0.046 & 0.140 & 0.090 & 0.141 & 0.111 & 0.055 & 0.061 & -0.059 & 0.128 & $0.356^{* *}$ & $0.288^{* *}$ & $0.240^{* *}$ & $0.288^{* *}$ & $0.343^{* *}$ & $0.328^{* *}$ \\
\hline
\end{tabular}


Table A2. Cont.

\begin{tabular}{|c|c|c|c|c|c|c|c|c|c|c|c|c|c|c|c|}
\hline & Q10.1 & Q10.2 & Q10.3 & Q10.4 & Q10.5 & Q10.6 & Q10.7 & Q10.8 & Q10.9 & Q11.1 & Q11.2 & Q11.3 & Q11.4 & Q11.5 & Q11.6 \\
\hline Q13.11 & 0.109 & 0.150 & 0.209 * & $0.247^{* *}$ & 0.135 & 0.105 & $0.177^{*}$ & 0.138 & 0.105 & $0.279 * *$ & $0.307^{* *}$ & 0.189 * & $0.304^{* *}$ & $0.225^{* *}$ & $0.268^{* *}$ \\
\hline Q13.12 & 0.129 & 0.194 * & $0.300^{* *}$ & $0.404^{* *}$ & $0.299 * *$ & $0.413^{* *}$ & $0.307^{* *}$ & 0.165 & 0.120 & 0.199 * & 0.060 & 0.009 & 0.060 & 0.197 * & 0.092 \\
\hline Q13.13 & $0.225^{* *}$ & $0.279 * *$ & $0.217^{*}$ & 0.210 * & 0.110 & 0.158 & $0.225^{* *}$ & 0.183 * & 0.159 & 0.189 * & 0.122 & 0.058 & 0.151 & 0.162 & 0.156 \\
\hline Q13.15 & 0.052 & $0.218^{*}$ & $0.314^{* *}$ & $0.217^{*}$ & 0.103 & 0.172 * & $0.395^{* *}$ & $0.369^{* *}$ & $0.228^{* *}$ & 0.145 & 0.174 * & 0.084 & 0.201 * & $0.291^{* *}$ & $0.265^{* *}$ \\
\hline Q13.16 & $0.196^{*}$ & $0.282^{* *}$ & $0.356^{* *}$ & $0.309^{* *}$ & 0.213 * & $0.273^{* *}$ & 0.422 ** & $0.357^{* *}$ & $0.231^{* *}$ & 0.201 * & 0.165 & 0.169 & 0.136 & $0.227^{* *}$ & $0.241^{* *}$ \\
\hline Q13.17 & 0.118 & $0.277^{* *}$ & $0.230^{* *}$ & 0.165 & 0.214 * & 0.169 & $0.337^{* *}$ & $0.260^{* *}$ & $0.184 *$ & $0.299 * *$ & $0.232^{* *}$ & $0.283^{* *}$ & $0.216^{*}$ & $0.384^{* *}$ & $0.399^{* *}$ \\
\hline Q13.18 & 0.156 & $0.238^{* *}$ & $0.276^{* *}$ & 0.197 * & 0.138 & $0.172 *$ & $0.317^{* *}$ & 0.192 * & 0.131 & $0.303^{* *}$ & $0.229^{* *}$ & $0.231^{* *}$ & 0.220 * & $0.301^{* *}$ & $0.326^{* *}$ \\
\hline Q13.20 & 0.117 & 0.154 & $0.332^{* *}$ & $0.241^{* *}$ & $0.221 *$ & 0.131 & $0.243^{* *}$ & 0.173 * & 0.041 & $0.266^{* *}$ & $0.216^{*}$ & $0.226^{* *}$ & $0.240^{* *}$ & $0.221 *$ & 0.193 * \\
\hline
\end{tabular}

Table A3. Pearson's correlation matrix, * significant at the alpha 0.05 level, ${ }^{* *}$ significant at the alpha 0.01 level.

\begin{tabular}{|c|c|c|c|c|c|c|c|c|c|c|}
\hline & Q11.7 & Q11.8 & Q11.9 & Q11.10 & Q13.1 & Q13.2 & Q13.3 & Q13.4 & Q13.5 & Q13.6 \\
\hline age & -0.059 & 0.024 & 0.016 & 0.000 & 0.134 & 0.140 & 0.152 & 0.098 & 0.136 & -0.036 \\
\hline years partyc & $-0.234^{* *}$ & -0.106 & -0.069 & -0.004 & -0.146 & -0.042 & 0.073 & -0.032 & -0.108 & -0.093 \\
\hline Q8.1 & 0.159 & 0.095 & 0.161 & 0.073 & 0.092 & 0.154 & 0.117 & 0.064 & 0.022 & $0.187^{*}$ \\
\hline Q8.3 & 0.102 & 0.105 & 0.099 & 0.108 & 0.022 & 0.075 & 0.160 & 0.089 & 0.083 & $0.256^{* *}$ \\
\hline Q9.1 & 0.093 & -0.026 & 0.059 & 0.022 & 0.085 & $0.319^{* *}$ & 0.074 & 0.042 & 0.081 & 0.017 \\
\hline Q9.2 & $0.273^{* *}$ & 0.222 * & $0.287^{* *}$ & 0.086 & $0.233^{* *}$ & $0.260^{* *}$ & 0.089 & 0.064 & 0.042 & 0.048 \\
\hline Q9.3 & $0.270^{* *}$ & 0.136 & $0.233^{* *}$ & 0.019 & 0.118 & 0.180 * & 0.039 & 0.046 & 0.142 & 0.122 \\
\hline Q9.5 & 0.143 & 0.195 * & 0.180 * & 0.070 & $0.204^{*}$ & 0.173 * & $0.290^{* *}$ & 0.173 * & 0.067 & 0.113 \\
\hline Q9.6 & 0.112 & 0.123 & 0.105 & 0.028 & $0.187^{*}$ & 0.157 & 0.212 * & 0.107 & 0.075 & 0.040 \\
\hline Q9.7 & 0.217 * & $0.208^{*}$ & $0.241^{* *}$ & 0.095 & 0.260 ** & $0.250^{* *}$ & 0.126 & 0.078 & 0.139 & 0.191 * \\
\hline Q9.8 & 0.126 & 0.191 * & $0.229 * *$ & 0.125 & $0.226^{* *}$ & $0.267^{* *}$ & 0.163 & 0.164 & $0.216^{*}$ & 0.221 * \\
\hline Q9.9 & 0.157 & 0.163 & $0.239 * *$ & 0.150 & $0.179 *$ & $0.265^{* *}$ & 0.161 & 0.105 & 0.193 * & 0.183 * \\
\hline Q9.10 & $0.246^{* *}$ & $0.227^{* *}$ & $0.270^{* *}$ & 0.072 & 0.140 & 0.124 & 0.159 & 0.016 & 0.049 & 0.182 * \\
\hline Q10.1 & 0.033 & 0.112 & 0.045 & -0.015 & 0.074 & 0.050 & 0.139 & 0.059 & -0.037 & -0.061 \\
\hline Q10.2 & 0.025 & -0.003 & -0.061 & -0.029 & 0.131 & 0.071 & 0.205 * & 0.095 & 0.036 & 0.142 \\
\hline Q10.3 & 0.078 & 0.100 & 0.115 & 0.180 * & 0.140 & 0.132 & 0.113 & 0.116 & 0.051 & 0.176 * \\
\hline Q10.6 & 0.160 & 0.080 & 0.139 & 0.193 * & 0.091 & 0.101 & $0.251^{* *}$ & 0.171 * & 0.120 & 0.179 * \\
\hline
\end{tabular}


Table A3. Cont.

\begin{tabular}{|c|c|c|c|c|c|c|c|c|c|c|}
\hline & Q11.7 & Q11.8 & Q11.9 & Q11.10 & Q13.1 & Q13.2 & Q13.3 & Q13.4 & Q13.5 & Q13.6 \\
\hline Q10.7 & 0.128 & 0.137 & 0.146 & 0.174 * & 0.164 & 0.204 * & $0.224^{* *}$ & 0.088 & 0.093 & 0.158 \\
\hline Q10.8 & 0.117 & 0.105 & 0.119 & 0.136 & 0.108 & 0.120 & 0.165 & 0.011 & -0.005 & 0.019 \\
\hline Q10.9 & $0.237^{* *}$ & 0.189 * & $0.274^{* *}$ & 0.147 & 0.196 * & 0.159 & 0.195 * & 0.079 & 0.014 & 0.216 * \\
\hline Q11.2 & 0.661 ** & 0.602 ** & $0.574^{* *}$ & $0.424^{* *}$ & $0.433^{* *}$ & $0.307^{* *}$ & 0.232 ** & 0.200 * & 0.205 * & 0.210 * \\
\hline Q11.3 & $0.579^{* *}$ & $0.502^{* *}$ & $0.443^{* *}$ & $0.396^{* *}$ & $0.293^{* *}$ & 0.203 * & 0.144 & $0.232 * *$ & $0.243^{* *}$ & $0.287^{* *}$ \\
\hline Q11.4 & $0.644^{* *}$ & $0.704^{* *}$ & $0.679 * *$ & $0.551^{* *}$ & $0.470^{* *}$ & $0.345^{* *}$ & $0.226^{* *}$ & $0.245^{* *}$ & $0.224^{* *}$ & 0.107 \\
\hline Q11.5 & $0.629^{* *}$ & $0.609^{* *}$ & $0.708^{* *}$ & $0.546^{* *}$ & $0.294^{* *}$ & $0.337^{* *}$ & 0.191 * & 0.212 * & $0.265^{* *}$ & $0.231^{* *}$ \\
\hline Q11.7 & 1 & $0.666^{* *}$ & $0.626^{* *}$ & $0.549^{* *}$ & $0.326^{* *}$ & $0.307^{* *}$ & $0.206^{*}$ & $0.233^{* *}$ & 0.350 ** & 0.250 ** \\
\hline Q11.8 & $0.666^{* *}$ & 1 & $0.842^{* *}$ & $0.637^{* *}$ & $0.427^{* *}$ & $0.348^{* *}$ & $0.246^{* *}$ & $0.319^{* *}$ & $0.288^{* *}$ & 0.071 \\
\hline Q11.9 & $0.626^{* *}$ & $0.842^{* *}$ & 1 & $0.638^{* *}$ & $0.351^{* *}$ & $0.452^{* *}$ & $0.280^{* *}$ & $0.305^{* *}$ & $0.297^{* *}$ & $0.197^{*}$ \\
\hline Q11.10 & $0.549^{* *}$ & $0.637^{* *}$ & $0.638^{* *}$ & 1 & $0.311^{* *}$ & $0.363^{* *}$ & $0.363^{* *}$ & $0.466^{* *}$ & $0.502^{* *}$ & 0.191 * \\
\hline Q13.1 & $0.326^{* *}$ & $0.427^{* *}$ & $0.351^{* *}$ & $0.311^{* *}$ & 1 & $0.704^{* *}$ & $0.483^{* *}$ & $0.457^{* *}$ & $0.427^{* *}$ & 0.040 \\
\hline Q13.2 & $0.307^{* *}$ & $0.348^{* *}$ & 0.452 ** & 0.363 ** & $0.704^{* *}$ & 1 & $0.567^{* *}$ & $0.623^{* *}$ & $0.591^{* *}$ & 0.193 * \\
\hline Q13.3 & 0.206 * & $0.246^{* *}$ & 0.280 ** & 0.363 ** & $0.483^{* *}$ & $0.567^{* *}$ & 1 & $0.580^{* *}$ & $0.421^{* *}$ & $0.300^{* *}$ \\
\hline Q13.4 & $0.233^{* *}$ & $0.319^{* *}$ & $0.305^{* *}$ & $0.466^{* *}$ & $0.457 * *$ & $0.623 * *$ & $0.580 * *$ & 1 & $0.766^{* *}$ & $0.322^{* *}$ \\
\hline Q13.5 & $0.350^{* *}$ & $0.288^{* *}$ & $0.297^{* *}$ & $0.502^{* *}$ & $0.427^{* *}$ & 0.591 ** & $0.421^{* *}$ & $0.766^{* *}$ & 1 & 0.369 ** \\
\hline Q13.7 & $0.228^{* *}$ & $0.298^{* *}$ & $0.384^{* *}$ & $0.494^{* *}$ & $0.358^{* *}$ & $0.536^{* *}$ & $0.435^{* *}$ & 0.598 ** & $0.517^{* *}$ & $0.347^{* *}$ \\
\hline Q13.8 & 0.151 & 0.231 ** & 0.210 * & $0.303^{* *}$ & $0.348^{* *}$ & $0.457^{* *}$ & $0.362^{* *}$ & 0.491 ** & $0.373^{* *}$ & 0.172 * \\
\hline Q13.9 & 0.142 & 0.124 & $0.231^{* *}$ & 0.199 * & $0.267^{* *}$ & $0.304^{* *}$ & $0.346^{* *}$ & $0.315^{* *}$ & $0.266^{* *}$ & $0.353^{* *}$ \\
\hline Q13.10 & $0.327^{* *}$ & $0.376^{* *}$ & 0.489 ** & $0.353^{* *}$ & 0.390 ** & 0.609 ** & $0.361^{* *}$ & $0.530^{* *}$ & $0.548^{* *}$ & $0.518^{* *}$ \\
\hline Q13.11 & 0.329 ** & $0.444^{* *}$ & 0.397 ** & 0.440 ** & $0.554^{* *}$ & $0.437^{* *}$ & $0.482 * *$ & $0.411^{* *}$ & $0.423^{* *}$ & 0.147 \\
\hline Q13.12 & 0.174 * & 0.133 & $0.292 * *$ & $0.406^{* *}$ & 0.106 & $0.256^{* *}$ & $0.416^{* *}$ & $0.314^{* *}$ & $0.300^{* *}$ & $0.428^{* *}$ \\
\hline Q13.13 & 0.182 * & $0.307^{* *}$ & $0.307^{* *}$ & $0.256^{* *}$ & $0.341^{* *}$ & $0.380^{* *}$ & $0.372^{* *}$ & 0.452 ** & $0.380^{* *}$ & 0.059 \\
\hline Q13.14 & 0.099 & 0.188 * & $0.306^{* *}$ & $0.258^{* *}$ & 0.144 & $0.303^{* *}$ & 0.242 ** & $0.365^{* *}$ & $0.324^{* *}$ & $0.339^{* *}$ \\
\hline Q13.15 & $0.283^{* *}$ & $0.281^{* *}$ & $0.365^{* *}$ & $0.419^{* *}$ & $0.349^{* *}$ & $0.425^{* *}$ & $0.428^{* *}$ & $0.346^{\text {** }}$ & $0.340^{* *}$ & $0.259^{* *}$ \\
\hline Q13.16 & 0.220 * & $0.242^{* *}$ & $0.289^{* *}$ & $0.225^{* *}$ & 0.211 * & $0.264^{* *}$ & $0.293^{* *}$ & 0.193 * & $0.207^{*}$ & $0.326^{* *}$ \\
\hline Q13.17 & $0.309^{* *}$ & $0.314^{* *}$ & $0.361^{* *}$ & $0.278^{* *}$ & $0.282^{* *}$ & $0.327^{* *}$ & 0.302 ** & $0.243^{* *}$ & $0.261^{* *}$ & $0.254^{* *}$ \\
\hline Q13.18 & $0.370^{* *}$ & $0.347^{* *}$ & $0.358^{* *}$ & $0.312^{* *}$ & 0.300 ** & $0.368^{* *}$ & 0.296 ** & 0.223 * & $0.273^{* *}$ & 0.185 * \\
\hline Q13.19 & $0.405^{* *}$ & 0.324 ** & $0.354^{* *}$ & $0.327^{* *}$ & $0.338^{* *}$ & $0.366^{* *}$ & $0.309 * *$ & $0.297^{* *}$ & 0.339 ** & $0.257^{* *}$ \\
\hline Q13.20 & 0.203 * & $0.305^{* *}$ & 0.222 * & $0.322 * *$ & $0.302^{* *}$ & $0.263^{* *}$ & $0.270^{* *}$ & 0.220 * & 0.197 * & 0.043 \\
\hline
\end{tabular}


Table A4. Pearson's correlation matrix, * significant at the alpha 0.05 level, ${ }^{* *}$ significant at the alpha 0.01 level.

\begin{tabular}{|c|c|c|c|c|c|c|c|c|c|c|c|c|c|c|}
\hline & Q13.7 & Q13.8 & Q13.9 & Q13.10 & Q13.11 & Q13.12 & Q13.13 & Q13.14 & Q13.15 & Q13.16 & Q13.17 & Q13.18 & Q13.19 & Q13.20 \\
\hline age & 0.102 & 0.158 & 0.141 & 0.094 & 0.172 * & -0.010 & 0.155 & 0.171 & 0.149 & 0.087 & 0.079 & 0.055 & 0.025 & 0.010 \\
\hline $\begin{array}{l}\text { years } \\
\text { partyc }\end{array}$ & 0.002 & -0.057 & 0.094 & -0.113 & -0.035 & 0.085 & -0.042 & 0.168 & 0.008 & -0.025 & -0.044 & -0.051 & -0.100 & -0.037 \\
\hline Q8.2 & 0.144 & 0.098 & $0.245^{* *}$ & $0.279 * *$ & 0.209 * & 0.196 * & 0.130 & 0.151 & $0.192 *$ & 0.184 * & 0.167 & 0.149 & 0.150 & -0.006 \\
\hline Q8.3 & 0.180 * & 0.082 & 0.121 & 0.102 & 0.107 & 0.087 & 0.023 & -0.018 & -0.007 & 0.078 & 0.029 & 0.048 & -0.007 & 0.043 \\
\hline Q9.1 & 0.048 & 0.065 & 0.197 * & 0.158 & 0.015 & 0.187 * & 0.115 & 0.140 & 0.147 & 0.040 & 0.129 & $0.176^{*}$ & $0.249^{* *}$ & 0.033 \\
\hline Q9.2 & -0.012 & 0.063 & $0.255^{* *}$ & 0.220 * & 0.136 & 0.192 * & 0.192 * & 0.148 & 0.214 * & 0.147 & 0.208 * & $0.276^{* *}$ & $0.355^{* *}$ & 0.105 \\
\hline Q9.4 & -0.068 & -0.080 & 0.010 & 0.105 & -0.110 & 0.106 & 0.087 & 0.052 & 0.042 & 0.139 & 0.149 & 0.011 & 0.181 * & -0.093 \\
\hline Q9.5 & 0.032 & 0.069 & $0.312^{* *}$ & 0.143 & 0.193 * & 0.189 * & 0.073 & 0.020 & $0.225^{* *}$ & $0.260^{* *}$ & 0.205 * & 0.116 & 0.168 & 0.040 \\
\hline Q9.6 & -0.018 & 0.111 & 0.231 ** & 0.077 & 0.099 & 0.112 & 0.048 & -0.055 & 0.104 & 0.077 & 0.058 & 0.048 & 0.106 & 0.055 \\
\hline Q9.7 & 0.116 & 0.113 & $0.312 * *$ & $0.266^{* *}$ & 0.235 ** & 0.194 * & 0.222 * & 0.133 & $0.236^{* *}$ & $0.229 * *$ & 0.204 * & $0.252 * *$ & $0.319^{* *}$ & 0.160 \\
\hline Q9.8 & 0.141 & 0.097 & $0.359 * *$ & 0.313 ** & $0.284^{* *}$ & $0.275^{* *}$ & $0.257^{* *}$ & 0.206 * & $0.303^{* *}$ & $0.359 * *$ & $0.288^{* *}$ & $0.315^{* *}$ & $0.376^{* *}$ & 0.219 * \\
\hline Q9.9 & 0.161 & 0.182 * & 0.328 ** & $0.283^{* *}$ & 0.208 * & $0.273^{* *}$ & $0.285^{* *}$ & 0.194 * & 0.359 ** & 0.353 ** & $0.275^{* *}$ & 0.330 ** & $0.381^{* *}$ & 0.196 * \\
\hline Q9.10 & -0.011 & 0.098 & 0.203 * & 0.141 & 0.179 * & 0.054 & 0.061 & 0.028 & 0.054 & $0.249 * *$ & 0.136 & 0.164 & 0.172 * & -0.025 \\
\hline Q10.1 & -0.057 & -0.035 & 0.107 & 0.046 & 0.109 & 0.129 & $0.225^{* *}$ & 0.188 * & 0.052 & 0.196 * & 0.118 & 0.156 & 0.167 & 0.117 \\
\hline Q10.2 & -0.030 & 0.125 & $0.254^{* *}$ & 0.140 & 0.150 & 0.194 * & $0.279 * *$ & 0.142 & $0.218 *$ & $0.282 * *$ & $0.277^{* *}$ & $0.238^{* *}$ & $0.339^{* *}$ & 0.154 \\
\hline Q10.4 & 0.140 & 0.056 & $0.369^{* *}$ & 0.141 & $0.247^{* *}$ & $0.404^{* *}$ & 0.210 * & $0.253 * *$ & $0.217 *$ & $0.309^{* *}$ & 0.165 & 0.197 * & $0.253^{* *}$ & 0.241 ** \\
\hline Q10.5 & -0.018 & -0.138 & $0.172 *$ & 0.111 & 0.135 & $0.299^{* *}$ & 0.110 & 0.179 * & 0.103 & $0.213 *$ & $0.214^{*}$ & 0.138 & $0.242^{* *}$ & 0.221 * \\
\hline Q10.6 & 0.018 & -0.109 & 0.209 * & 0.055 & 0.105 & $0.413^{* *}$ & 0.158 & $0.274^{* *}$ & 0.172 * & $0.273^{* *}$ & 0.169 & 0.172 * & $0.318^{* *}$ & 0.131 \\
\hline Q10.7 & 0.002 & -0.002 & -0.003 & 0.061 & $0.177^{*}$ & $0.307^{* *}$ & $0.225^{* *}$ & 0.230 ** & $0.395^{* *}$ & 0.422 ** & $0.337^{* *}$ & $0.317^{* *}$ & $0.313^{* *}$ & $0.243^{* *}$ \\
\hline Q10.8 & -0.046 & -0.064 & 0.079 & -0.059 & 0.138 & 0.165 & 0.183 * & $0.211^{*}$ & $0.369 * *$ & 0.357 ** & $0.260 * *$ & 0.192 * & $0.209 *$ & 0.173 * \\
\hline Q10.9 & -0.057 & -0.133 & 0.015 & 0.128 & 0.105 & 0.120 & 0.159 & $0.245^{* *}$ & 0.228 ** & 0.231 ** & 0.184 * & 0.131 & 0.181 * & 0.041 \\
\hline Q11.1 & 0.209 * & $0.176^{*}$ & 0.156 & $0.356^{* *}$ & $0.279 * *$ & 0.199 * & 0.189 * & 0.111 & 0.145 & 0.201 * & $0.299 * *$ & $0.303^{* *}$ & $0.399 * *$ & $0.266^{* *}$ \\
\hline Q11.2 & $0.261 * *$ & 0.151 & 0.095 & 0.288 ** & $0.307 * *$ & 0.060 & 0.122 & 0.103 & 0.174 * & 0.165 & 0.232 ** & $0.229 * *$ & $0.297 * *$ & 0.216 * \\
\hline Q11.3 & 0.220 * & 0.196 * & 0.047 & 0.240 ** & 0.189 * & 0.009 & 0.058 & 0.070 & 0.084 & 0.169 & 0.283 ** & $0.231 * *$ & $0.298^{* *}$ & 0.226 ** \\
\hline Q11.4 & $0.225^{* *}$ & 0.213 * & 0.144 & 0.288 ** & $0.304^{* *}$ & 0.060 & 0.151 & 0.069 & 0.201 * & 0.136 & $0.216^{*}$ & 0.220 * & $0.314^{* *}$ & 0.240 ** \\
\hline Q11.5 & $0.257^{* *}$ & 0.121 & 0.114 & 0.343 ** & $0.225^{* *}$ & 0.197 * & 0.162 & 0.170 & $0.291^{* *}$ & $0.227^{* *}$ & $0.384^{* *}$ & 0.301 ** & $0.411^{* *}$ & 0.221 * \\
\hline Q11.6 & 0.185 * & 0.037 & 0.044 & 0.328 ** & $0.268^{* *}$ & 0.092 & 0.156 & 0.130 & $0.265^{* *}$ & 0.241 ** & $0.399 * *$ & $0.326^{* *}$ & $0.425^{* *}$ & 0.193 * \\
\hline Q11.7 & $0.228^{* *}$ & 0.151 & 0.142 & 0.327 ** & $0.329 * *$ & 0.174 * & 0.182 * & 0.099 & 0.283 ** & 0.220 * & 0.309 ** & 0.370 ** & $0.405 * *$ & 0.203 * \\
\hline Q11.8 & 0.298 ** & $0.231^{* *}$ & 0.124 & 0.376 ** & $0.444^{* *}$ & 0.133 & $0.307^{* *}$ & 0.188 * & 0.281 ** & 0.242 ** & $0.314^{* *}$ & $0.347^{* *}$ & 0.324 ** & $0.305^{* *}$ \\
\hline Q11.9 & $0.384^{* *}$ & 0.210 * & $0.231 * *$ & $0.489^{* *}$ & $0.397^{* *}$ & 0.292 ** & $0.307^{* *}$ & $0.306^{* *}$ & $0.365^{* *}$ & $0.289 * *$ & $0.361 * *$ & $0.358^{* *}$ & $0.354^{* *}$ & 0.222 * \\
\hline Q11.10 & $0.494^{* *}$ & $0.303^{* *}$ & $0.199 *$ & 0.353 ** & $0.440 * *$ & $0.406^{* *}$ & $0.256^{* *}$ & $0.258^{* *}$ & $0.419^{* *}$ & $0.225^{* *}$ & $0.278^{* *}$ & $0.312^{* *}$ & $0.327^{* *}$ & 0.322 ** \\
\hline
\end{tabular}


Table A4. Cont.

\begin{tabular}{|c|c|c|c|c|c|c|c|c|c|c|c|c|c|c|}
\hline & Q13.7 & Q13.8 & Q13.9 & Q13.10 & Q13.11 & Q13.12 & Q13.13 & Q13.14 & Q13.15 & Q13.16 & Q13.17 & Q13.18 & Q13.19 & Q13.20 \\
\hline Q13.1 & $0.358^{* *}$ & $0.348^{* *}$ & $0.267^{* *}$ & $0.390^{* *}$ & $0.554^{* *}$ & 0.106 & $0.341^{* *}$ & 0.144 & $0.349^{* *}$ & $0.211^{*}$ & $0.282^{* *}$ & $0.300^{* *}$ & $0.338^{* *}$ & 0.302 ** \\
\hline Q13.2 & $0.536^{* *}$ & $0.457^{* *}$ & $0.304^{* *}$ & $0.609 * *$ & $0.437^{* *}$ & $0.256^{* *}$ & $0.380^{* *}$ & $0.303^{* *}$ & $0.425^{* *}$ & $0.264^{* *}$ & $0.327^{* *}$ & $0.368^{* *}$ & $0.366^{* *}$ & $0.263^{* *}$ \\
\hline Q13.3 & $0.435^{* *}$ & $0.362 * *$ & $0.346^{* *}$ & $0.361 * *$ & $0.482 * *$ & $0.416^{* *}$ & $0.372^{* *}$ & $0.242^{* *}$ & $0.428 * *$ & $0.293^{* *}$ & $0.302 * *$ & $0.296^{* *}$ & $0.309 * *$ & $0.270 * *$ \\
\hline Q13.5 & $0.517^{* *}$ & $0.373^{* *}$ & $0.266^{* *}$ & $0.548^{* *}$ & $0.423^{* *}$ & $0.300^{* *}$ & $0.380^{* *}$ & $0.324^{* *}$ & $0.340^{* *}$ & $0.207^{*}$ & $0.261^{* *}$ & $0.273^{* *}$ & $0.339 * *$ & 0.197 * \\
\hline Q13.6 & $0.347^{* *}$ & 0.172 * & $0.353^{* *}$ & $0.518^{* *}$ & 0.147 & $0.428^{* *}$ & 0.059 & $0.339^{* *}$ & $0.259^{* *}$ & $0.326^{* *}$ & $0.254^{* *}$ & 0.185 * & $0.257^{* *}$ & 0.043 \\
\hline Q13.7 & 1 & $0.519 * *$ & $0.428^{* *}$ & $0.565^{* *}$ & 0.370 ** & $0.367^{* *}$ & $0.321^{* *}$ & $0.339^{* *}$ & $0.385^{* *}$ & 0.194 * & 0.201 * & $0.253^{* *}$ & $0.254^{* *}$ & $0.282 * *$ \\
\hline Q13.8 & $0.519^{* *}$ & 1 & $0.357^{* *}$ & $0.394^{* *}$ & $0.360 * *$ & $0.191 *$ & $0.361^{* *}$ & $0.178^{*}$ & $0.279 * *$ & 0.161 & 0.155 & $0.232^{* *}$ & $0.229^{* *}$ & $0.257^{* *}$ \\
\hline Q13.10 & $0.565^{* *}$ & $0.394^{* *}$ & $0.440^{* *}$ & 1 & $0.510^{* *}$ & $0.362^{* *}$ & $0.391^{* *}$ & $0.302^{* *}$ & $0.356^{* *}$ & $0.286^{* *}$ & $0.369^{* *}$ & $0.375^{* *}$ & $0.440^{* *}$ & $0.288^{* *}$ \\
\hline Q13.11 & $0.370 * *$ & $0.360 * *$ & $0.362 * *$ & $0.510 * *$ & 1 & $0.427^{* *}$ & $0.527^{* *}$ & $0.269^{* *}$ & $0.467^{* *}$ & $0.354^{* *}$ & $0.366^{* *}$ & $0.412^{* *}$ & $0.460 * *$ & $0.431^{* *}$ \\
\hline Q13.12 & $0.367^{* *}$ & 0.191 * & $0.436^{* *}$ & $0.362 * *$ & $0.427^{* *}$ & 1 & $0.368^{* *}$ & $0.461^{* *}$ & $0.450 * *$ & $0.293^{* *}$ & $0.230 * *$ & $0.320^{* *}$ & $0.378^{* *}$ & 0.166 \\
\hline Q13.13 & $0.321^{* *}$ & $0.361^{* *}$ & $0.292^{* *}$ & $0.391^{* *}$ & $0.527 * *$ & $0.368^{* *}$ & 1 & $0.581^{* *}$ & $0.538^{* *}$ & $0.316^{* *}$ & $0.388^{* *}$ & $0.509^{* *}$ & $0.457^{* *}$ & $0.376^{* *}$ \\
\hline Q13.14 & $0.339 * *$ & $0.178^{*}$ & $0.347^{* *}$ & $0.302 * *$ & $0.269 * *$ & $0.461^{* *}$ & $0.581^{* *}$ & 1 & $0.518^{* *}$ & $0.378^{* *}$ & $0.278^{* *}$ & $0.368^{* *}$ & $0.336^{* *}$ & 0.139 \\
\hline Q13.15 & $0.385^{* *}$ & $0.279^{* *}$ & $0.286^{* *}$ & 0.356 ** & $0.467^{* *}$ & 0.450 ** & $0.538^{* *}$ & $0.518^{* *}$ & 1 & $0.704^{* *}$ & $0.678^{* *}$ & $0.706^{* *}$ & $0.607^{* *}$ & $0.490^{* *}$ \\
\hline Q13.16 & 0.194 * & 0.161 & $0.227^{* *}$ & $0.286^{* *}$ & $0.354^{* *}$ & $0.293^{* *}$ & $0.316^{* *}$ & $0.378^{* *}$ & $0.704^{* *}$ & 1 & $0.781^{* *}$ & $0.730^{* *}$ & $0.649 * *$ & 0.581 ** \\
\hline Q13.17 & $0.201 *$ & 0.155 & 0.139 & $0.369 * *$ & $0.366^{* *}$ & $0.230^{* *}$ & $0.388^{* *}$ & $0.278^{* *}$ & $0.678^{* *}$ & $0.781^{* *}$ & 1 & $0.807^{* *}$ & $0.767^{* *}$ & $0.648^{* *}$ \\
\hline Q13.18 & $0.253^{* *}$ & $0.232^{* *}$ & $0.179 *$ & $0.375^{* *}$ & $0.412 * *$ & $0.320^{* *}$ & $0.509^{* *}$ & $0.368^{* *}$ & $0.706^{* *}$ & $0.730^{* *}$ & $0.807^{* *}$ & 1 & $0.833^{* *}$ & $0.690^{* *}$ \\
\hline Q13.20 & $0.282 * *$ & $0.257^{* *}$ & 0.147 & $0.288^{* *}$ & $0.431^{* *}$ & 0.166 & $0.376^{* *}$ & 0.139 & $0.490 * *$ & $0.581 * *$ & $0.648^{* *}$ & $0.690^{* *}$ & $0.621^{* *}$ & 1 \\
\hline
\end{tabular}


Table A5. Eigenvalues and proportion of the total variance in 9 groups of collective entrepreneurship, as explained by the first three principal components for the original 19 traits and the correlation coefficients between these traits and the first three PCs on for questions Q9 and Q10.

\begin{tabular}{|c|c|c|c|c|c|}
\hline & \multicolumn{5}{|c|}{ Component } \\
\hline & 1 & 2 & 3 & 4 & 5 \\
\hline Q9.1 & 0.945 & -0.018 & 0.146 & 0.217 & 0.115 \\
\hline Q9.2 & 0.423 & 0.015 & 0.715 & 0.202 & 0.462 \\
\hline Q9.3 & 0.075 & -0.086 & 0.901 & 0.213 & 0.259 \\
\hline Q9.4 & 0.884 & 0.119 & -0.079 & 0.283 & -0.227 \\
\hline Q9.5 & 0.542 & -0.257 & 0.630 & 0.066 & 0.204 \\
\hline Q9.6 & 0.365 & 0.670 & -0.528 & 0.246 & -0.022 \\
\hline Q9.7 & 0.278 & 0.489 & 0.009 & 0.774 & 0.021 \\
\hline Q9.8 & 0.693 & 0.298 & -0.015 & 0.641 & 0.113 \\
\hline Q9.9 & 0.698 & 0.357 & -0.041 & 0.471 & 0.164 \\
\hline Q9.10 & 0.543 & 0.616 & 0.212 & 0.299 & 0.347 \\
\hline Q10.1 & -0.154 & -0.049 & 0.299 & -0.113 & 0.917 \\
\hline $\mathrm{Q} 10.2$ & 0.090 & 0.209 & 0.188 & -0.026 & 0.873 \\
\hline Q10.3 & 0.557 & 0.271 & 0.633 & 0.050 & -0.421 \\
\hline Q10.4 & -0.194 & 0.293 & 0.862 & 0.049 & 0.180 \\
\hline Q10.5 & 0.454 & -0.281 & 0.208 & 0.695 & -0.122 \\
\hline Q10.6 & 0.228 & -0.208 & 0.246 & 0.893 & -0.134 \\
\hline Q10.7 & 0.714 & 0.526 & 0.197 & 0.178 & -0.318 \\
\hline Q10.8 & 0.126 & 0.922 & -0.002 & -0.327 & 0.090 \\
\hline Q10.9 & -0.006 & 0.879 & 0.106 & 0.072 & 0.031 \\
\hline \multicolumn{6}{|c|}{ Total Variance Explained-Rotation Sums of Squared Loadings } \\
\hline Total & 4.789 & 3.598 & 3.495 & 3.042 & 2.504 \\
\hline$\%$ of Variance & 25.207 & 18.936 & 18.397 & 16.009 & 13.178 \\
\hline Cumulative \% & 25.207 & 44.143 & 62.540 & 78.548 & 91.727 \\
\hline
\end{tabular}

Extraction Method: Principal Component Analysis. Rotation Method: Varimax with Kaiser Normalization.

Table A6. Eigenvalues and proportion of the total variance in 9 groups of collective entrepreneurship, as explained by the first three principal components for the original 20 traits and the correlation coefficients between these traits and the first three PCs on for questions Q13.

\begin{tabular}{ccccc}
\hline & & \multicolumn{3}{c}{ Component } \\
\cline { 2 - 5 } & $\mathbf{1}$ & $\mathbf{2}$ & $\mathbf{3}$ & $\mathbf{4}$ \\
\hline Q13.1 & 0.157 & 0.935 & 0.111 & -0.131 \\
Q13.2 & 0.657 & 0.740 & 0.012 & -0.034 \\
Q13.3 & 0.366 & 0.891 & 0.165 & 0.061 \\
Q13.4 & 0.922 & 0.194 & 0.303 & -0.043 \\
Q13.5 & 0.840 & 0.224 & 0.455 & -0.021 \\
Q13.6 & 0.687 & -0.235 & 0.231 & 0.286 \\
Q13.7 & 0.888 & 0.114 & 0.284 & 0.233 \\
Q13.8 & 0.771 & 0.203 & 0.529 & -0.155 \\
Q13.9 & 0.215 & 0.066 & 0.856 & 0.045 \\
Q13.10 & 0.967 & 0.170 & 0.069 & 0.162 \\
Q13.11 & 0.458 & 0.711 & 0.507 & -0.064 \\
Q13.12 & 0.807 & 0.206 & 0.410 & 0.473 \\
Q13.13 & 0.786 & 0.349 & 0.378 & 0.980 \\
Q13.14 & 0.306 & 0.751 & 0.076 & 0.553 \\
Q13.15 & 0.147 & 0.053 & -0.630 & 0.008 \\
Q13.16 & -0.255 & -0.457 & -0.862 & 0.462 \\
Q13.17 & -0.145 & -0.084 & -0.443 & 0.049 \\
Q13.18 & 0.301 & -0.629 & 0.079 & 0.378 \\
Q13.19 & 0.317 & -0.889 & -0.269 & \\
Q13.20 & 0.833 & -0.204 & & \\
\end{tabular}


Table A6. Cont.

\begin{tabular}{|c|c|c|c|c|}
\hline & \multicolumn{4}{|c|}{ Component } \\
\hline & 1 & 2 & 3 & 4 \\
\hline \multicolumn{5}{|c|}{ Total Variance Explained-Rotation Sums of Squared Loadings } \\
\hline Total & 7.546 & 5.124 & 3.552 & 2.115 \\
\hline$\%$ of Variance & 37.732 & 25.621 & 17.761 & 10.574 \\
\hline Cumulative $\%$ & 37.732 & 63.353 & 81.114 & 91.688 \\
\hline
\end{tabular}

Extraction Method: Principal Component Analysis. Rotation Method: Varimax with Kaiser Normalization.

Table A7. Eigenvalues and proportion of the total variance in 9 groups of collective entrepreneurship, as explained by the first three principal components for the original 10 traits and the correlation coefficients between these traits and the first three PCs on for questions Q11.

\begin{tabular}{ccc}
\hline & \multicolumn{2}{c}{ Component } \\
\cline { 2 - 3 } & $\mathbf{1}$ & $\mathbf{2}$ \\
\hline Q11.1 & 0.171 & 0.949 \\
Q11.2 & 0.160 & 0.976 \\
Q11.3 & 0.164 & 0.963 \\
Q11.4 & 0.597 & -0.674 \\
Q11.5 & 0.938 & 0.082 \\
Q11.6 & 0.679 & 0.166 \\
Q11.7 & 0.935 & 0.081 \\
Q11.8 & 0.544 & 0.795 \\
Q11.9 & 0.889 & 0.392 \\
Q11.10 & 0.866 & 0.106 \\
\hline Total Variance Explained-Rotation Sums of Squared Loadings \\
\hline Total & 4.489 & 4.073 \\
\% of Variance & 44.889 & 40.733 \\
Cumulative \% & 44.889 & 85.622 \\
\hline
\end{tabular}

Extraction Method: Principal Component Analysis. Rotation Method: Varimax with Kaiser Normalization.

\section{References}

1. Statistics Poland. Agriculture in 2019; Statistics Poland: Warsaw, Poland, 2020; p. 15. Available online: https://stat.gov.pl/ obszary-tematyczne/rolnictwo-lesnictwo/rolnictwo/rolnictwo-w-2019-roku,3,16.html (accessed on 8 October 2021).

2. Nurzyńska, I.; Drygas, M. Rural Development Policy in Poland (and in the EU)—A Needless Expense or a Must? Wieś Rol. 2018, 179, 169-187. [CrossRef]

3. Boldureanu, G.; Ionescu, A.M.; Bercu, A.-M.; Bedrule-Grigoruță, M.V.; Boldureanu, D. Entrepreneurship Education through Successful Entrepreneurial Models in Higher Education Institutions. Sustainability 2020, 12, 1267. [CrossRef]

4. Huang, B.; Tani, M.; Zhu, Y. Does higher education make you more entrepreneurial? Causal evidence from China. JBR 2021, 135, 543-558. [CrossRef]

5. Nowakowska-Grunt, J.; Parzonko, A.J.; Kiełbasa, B. Determinants of Managing Networks of Organizations in Rural Areas; Publishing Office of Faculty of Management Częstochowa University of Technology: Częstochowa, Poland, 2016; pp. 51-54.

6. Korsgaard, S.; Müller, S.; Wittorff Tanvig, H. Rural entrepreneurship or entrepreneurship in the rural-Between place and space. IJEBR 2015, 21, 5-26. [CrossRef]

7. Galvão, A.R.; Mascarenhas, C.; Marques, C.S.E.; Braga, V.; Ferreira, M. Mentoring entrepreneurship in a rural territory-A qualitative exploration of an entrepreneurship program for rural areas. J. Rural. Stud. 2020, 78, 314-324. [CrossRef]

8. Minniti, M.; Lévesque, M. Entrepreneurial types and economic growth. J. Bus. Ventur. 2010, 25, 305-314. [CrossRef]

9. Ardichvili, A.; Cardozo, R.; Sourav, R. A Theory of Entrepreneurial Opportunity Identification and Development. J. Bus. Ventur. 2003, 18, 105-123. [CrossRef]

10. Shane, S. A General Theory of Entrepreneurship: The Individual-Opportunity Nexus; Edward Elgar: Northampton, MA, USA, 2003.

11. Krzyżanowska, K.; Parzonko, A.J.; Sieczko, A. Przedsiębiorczość Zespołowa na Obszarach Wiejskich. Stan i Perspektywy Rozwoju; WULS Press: Warszawa, Poland, 2020; pp. 16-19. Available online: https://www.ieif.sggw.pl/wp-content/uploads/2020/10/ Przedsiebiorczosc_Krzyzanowska_Parzonko_Sieczko.pdf (accessed on 8 October 2021).

12. Parzonko, A.J.; Sieczko, A. Agricultural producer groups as manifestation of team entrepreneurship in Poland. In Rural Development and Entrepreneurship: Production and Co-Operation in Agriculture, Proceedings of the International Scientific Conference, 
Vladivostok, Russia, 2-4 October 2018; Auzina, A., Ed.; Latvia University of Life Sciences and Technologies: Jelgava, Latvia, 2018; pp. 221-228.

13. Sztompka, P. Trust: A Sociological Theory; Cambridge University Press: Warsaw, Poland, 2000.

14. Lewenstein, B. Nowe paradygmaty rozwoju układów lokalnych. In Oblicza Lokalności. Różnorodność Miejsc i Czasu; Kurczewska, J., Ed.; Wydawnictwo IFiS PAN: Warszawa, Poland, 2006; p. 229.

15. Ayupova, S.; Bents, D.; Kozlova, E. Trust as a Factor of Interaction Efficiency. In Smart Technologies and Innovations in Design for Control of Technological Processes and Objects: Economy and Production. Smart Innovation, Systems and Technologies (139); Solovev, D., Ed.; Springer: Cham, Switzerland, 2019. [CrossRef]

16. Camarinha-Matos, L.M.; Afsarmanesh, H. Collaborative Networks. In Knowledge Enterprise: Intelligent Strategies in Product Design, Manufacturing, and Management. IFIP International Federation for Information Processing (207); Wang, K., Kovacs, G.L., Wozny, M., Fang, M., Eds.; Springer: Boston, MA, USA, 2006. [CrossRef]

17. Levin, D.Z.; Cross, R. The Strength of Weak Ties You Can Trust: The Mediating Role of Trust in Effective Knowledge. Transfer. Manag. Sci. 2004, 50, 1477-1490. [CrossRef]

18. Taylor, B.M.; Van Grieken, M. Local institutions and farmer participation in agri-environmental schemes. J. Rural. Stud. 2015, 37, 10-19. [CrossRef]

19. Quinn, B.; McKitterick, L.; Tregear, A.; McAdam, R. Trust in the programme: An exploration of trust dynamics within rural group-based support programmes. J. Rural. Stud. 2021. [CrossRef]

20. Welter, F. "All you need is trust?" A critical review of the trust and entrepreneurship literature. Int. Small Bus. J. 2012, 30, 193-212. [CrossRef]

21. Persky, J.J. Retrospectives The Ethology of Homo Economicus. J. Econ. Perspect. 1995, 9, 221-231. [CrossRef]

22. Bruni, L.; Guala, F. Vilfredo Pareto and the Epistemological Foundations of Choice Theory. HOPE 2001, 33, 21-49. Available online: http:/ / muse.jhu.edu/journals/hpe/summary/v033/33.1bruni.html (accessed on 8 October 2021). [CrossRef]

23. Milonakis, D.; Fine, B. From Political Economy to Economics. Method, the Social and the Historical in the Evolution of Economic Theory; Routledge: London, UK; New York, NY, USA, 2009; Available online: http:/ / pauladaunt.com/books/From_Political_Economy_ to_Freakonomics.pdf (accessed on 8 October 2021).

24. Thaler, R.H. Behavioral Economics: Past, Present, and Future. AER 2016, 106, 1577-1600. [CrossRef]

25. Smith, V. Microeconomic systems as an experimental science. AER 1982, 72, 923-955. Available online: https:/ /www.jstor.org/ stable/1812014 (accessed on 8 October 2021).

26. Samuelson, L. Game Theory in Economics and Beyond. JEP 2016, 30, 107-130. [CrossRef]

27. Mikłowicz, D. Zaufanie jako wartość społeczna. Studia Ekon. 2016, 259, 80-88.

28. Besser, T.; Miller, N. The structural, social and strategic factors associated with successful business networks. Enterpren. Reg. Dev. 2011, 23, 113-133. [CrossRef]

29. Newbery, R.; Sauer, J.; Gorton, M.; Phillipson, J.; Atterton, J. Determinants of the performance of business associations in rural settlements in the United Kingdom: An analysis of members' satisfaction and willingness-to-pay for association survival. Environ. Plann. 2013, 45, 967-985. [CrossRef]

30. Rauch, J.E. Productivity Gains from Geographic Concentration of Human Capital: Evidence from the Cities; Working Paper No. 3905; National Bureau of Economic Research: Cambridge, MA, USA, 1991; Available online: https://www.nber.org/system/files/ working_papers/w3905/w3905.pdf (accessed on 8 October 2021).

31. Chalker, M.; Loosemore, M. Trust and productivity in Australian construction projects: A subcontractor perspective. ECAM 2016, 23, 192-210. [CrossRef]

32. Kayes, A.; Kayes, D.C. Nurturing Trust. In The Learning Advantage; Palgrave Macmillan: London, UK, 2011; pp. 154-170. [CrossRef]

33. Sørensen, O.H.; Hasle, P.; Pejtersen, J.H. Trust relations in management of change. SJM 2011, 27, 405-417. [CrossRef]

34. Dincer, O.; Uslaner, E.M. Trust and growth. Public Choice 2010, 142, 59-67. [CrossRef]

35. Deelmann, T.; Loos, P. Trust economy: Aspects of reputation and trust building for SMEs in e-business in e-business. AMCIS 2002 Proc. 2002, 2002, 302. Available online: http:/ / aisel.aisnet.org/amcis2002/302 (accessed on 8 October 2021).

36. Khalifa, S. Trust, Landscape, And Economic Development. JED 2016, 41, 19-32. Available online: http://www.jed.or.kr/full-text/ 41-1/2.pdf (accessed on 8 October 2021).

37. Bjørnskov, C. Determinants of generalized trust: A cross-country comparison. Public Choice 2007, 130, 1-21. [CrossRef]

38. Algan, Y.; Cahuc, P. Inherited Trust and Growth. AER 2010, 100, 2060-2092. [CrossRef]

39. Elert, N.; Stam, E.; Stenkula, M. Intrapreneurship and Trust; Working Papers 19-08. U.S.E.; Research Institute: Utrecht, The Netherlands, 2019; pp. 1-27. Available online: https://www.uu.nl/sites/default/files/rebo_use_wp_2019_1908.pdf (accessed on 8 October 2021).

40. Dotti Sani, G.M.; Magistro, B. Increasingly unequal? The economic crisis, social inequalities and trust in the European Parliament in 20 European countries. EJPR 2016, 55, 246-264. [CrossRef]

41. Lipps, J.; Schraff, D. Regional inequality and institutional trust in Europe. EJPR 2021, 60, 892-913. [CrossRef]

42. Burciu, A.; Kicsi, R.; Bostan, I. Social Trust and Dynamics of Capitalist Economies in the Context of Clashing Managerial Factors with Risks and Severe Turbulence: A Conceptual Inquiry. Sustainability 2020, 12, 8794. [CrossRef] 
43. Gillath, O.; Ai, T.; Branicky, M.S.; Keshmiri, S.; Davison, R.B.; Spaulding, R. Attachment and trust in artificial intelligence. Comput. Hum. Behav. 2021, 115, 106607. [CrossRef]

44. Parzonko, A.; Balińska, A.; Sieczko, A. Pro-Environmental Behaviors of Generation Z in the Context of the Concept of Homo Socio-Oeconomicus. Energies 2021, 14, 1597. [CrossRef]

45. Munns, A. Potential influence of trust on the successful completion of a project. IJPM 1995, 13, 19-24. [CrossRef]

46. Blomqvist, K. The many faces of trust. SJM 1997, 13, 271-286. [CrossRef]

47. Hotte, N.; Kozak, R.; Wyatt, S. How institutions shape trust during collective action: A case study of forest governance on Haida Gwaii. For. Policy Econ. 2019, 107, 101921. [CrossRef]

48. Miller, G.J.; Whitford, A.B. Trust and incentives in principal-agent negotiations: The "insurance/incentive trade-off". JTP 2002, 14, 231-267. [CrossRef]

49. Cerić, A.; Vukomanović, M.; Ivić, I.; Kolarić, S. Trust in megaprojects: A comprehensive literature review of research trends. IJPM 2020, 39, 325-338. [CrossRef]

50. Paliszkiewicz, J. Zaufanie w Zarzadzaniu; WN PWN: Warsaw, Poland, 2013.

51. Krawczyk-Bryłka, B. Zaufanie do siebie jako jeden z aspektów zaufania w aktywności przedsiębiorczej. In Przedsiębiorczość: Jednostka, Organizacja, Kontekst; Postuła, A., Majczyk, J., Darecki, M., Eds.; Scientific Publishing House FMUW: Warsaw, Poland, 2015; pp. 90-102. [CrossRef]

52. Kwon, S.-W.; Arenius, P. Nations of entrepreneurs: A social capital perspective. JBV 2010, 25, 315-330. [CrossRef]

53. Ding, Z.; Au, K.; Chiang, F. Social trust and angel investors' decisions: A multilevel analysis across nations. JBV 2015, 30, 307-321. [CrossRef]

54. Centrum Badania Opinii Społecznej. Zaufanie Społeczne. Komunikat z Badań nr 43/2020; CBOS: Warszawa, Poland, 2020; Available online: https:/ / cbos.pl/SPISKOM.POL/2020/K_043_20.PDF (accessed on 8 October 2021).

55. Moczydłowska, J.M. Zaufanie jako determinanta relacji przedsiębiorcy_Przedstawiciele administracji samorządowej. Zarzadzanie Finanse 2012, 10, 75-85. Available online: http:/ /jmf.wzr.pl/pim/2012_4_2_6.pdf (accessed on 8 October 2021).

56. Trust Barometer. Global Report. Edelman. 2018. Available online: https://www.edelman.com/sites/g/files/aatuss191/files/20 18-10/2018_Edelman_Trust_Barometer_Global_Report_FEB.pdf (accessed on 21 December 2020).

57. Pan, L. Willingness of Farmers Joining Professional Cooperatives. Based on the Questionnaire Survey of Nanjing. Asian Agric. Res. 2011, 3, 1-5. [CrossRef]

58. Brodziński, Z. Entrepreneurship of Agricultural Producers-Determinants of Development. Ann. PAAAE 2019, 3. [CrossRef]

59. Phillipson, J.; Gorton, M.; Laschewski, L. Local Business Co-operation and the Dilemmas of Collective Action: Rural Microbusiness Networks in the North of England. Sociol. Rural. 2006, 46, 40-60. [CrossRef]

60. Sgroi, F.; Trapani, A.M.D.; Testa, R.; Tudisca, S. The Rural Tourism as Development Opportunity or Farms. The Case of Direct Sales in Sicily. AJABS 2014, 9, 407-419. [CrossRef]

61. Björklund, J.C. Barriers to Sustainable Business Model Innovation in Swedish Agriculture. JEMI 2018, 14, 65-90. [CrossRef]

62. Colombo, S.; Perujo-Villanueva, M. Analysis of the spatial relationship between small olive farms to increase their competitiveness through cooperation. Land Use Policy 2017, 63, 226-235. [CrossRef]

63. Krzyżanowska, K. Ekonomiczno-Społeczne Uwarunkowania Innowacji w Zespołowym Działaniu w Rolnictwie; WULS Press: Warsaw, Poland, 2016; Available online: https://www.ieif.sggw.pl/wp-content/uploads/2021/05/Ekonomiczno-spoleczne_ KrzyzanowskaK.pdf (accessed on 8 October 2021).

64. Fałkowski, J.; Chlebicka, A.; Łopaciuk-Gonczaryk, B. Social relationships and governing collaborative actions in rural areas: Some evidence from agricultural producer groups in Poland. J. Rural. Stud. 2017, 49, 104-116. [CrossRef]

65. do Adro, F.; Franco, M. Rural and agri-entrepreneurial networks: A qualitative case study. Land Use Policy $2020,99,105117$. [CrossRef]

66. Fortunato, M.W.P. Supporting rural entrepreneurship: A review of conceptual developments from research to practice. Community Dev. 2014, 45, 387-408. [CrossRef]

67. Skandrani, H.; Triki, A.; Baratli, B. Trust in supply chains, meanings, determinants and demonstrations: A qualitative study in an emerging market context. Qual. Mark. Res. 2011, 14, 391-409. [CrossRef]

68. Fawcett, S.E.; Jones, S.L.; Fawcett, A.M. Supply chain trust: The catalyst for collaborative innovation. Bus. Horiz. 2012, 55, 163-178. [CrossRef]

69. Day, M.; Fawcett, S.E.; Fawcett, A.M.; Magnan, G.M. Trust and relational embeddedness: Exploring a paradox of trust pattern development in key supplier relationships. Ind. Mark. Manag. 2013, 42, 152-165. [CrossRef]

70. Szabó, G.G. The importance and role of trust in agricultural marketing co-operatives. Stud. Agric. Econ. 2010, 112, 5-22. [CrossRef]

71. Pulfer, I.; Möhring, A.; Dobricki, M.; Lips, M. Success factors for farming collectives. In Proceedings of the 12th Congress of the European Association of Agricultural Economists-EAAE 2008, Ghent, Belgium, 26-29 August 2008. [CrossRef]

72. Davies, P.; Mason-Jones, R. Communities of interest as a lens to explore the advantage of collaborative behaviour for developing economies: An example of the Welsh organic food sector. IJEIM 2017, 18, 5-13. [CrossRef] 